\title{
Comparison of the Synoptic Environments Conducive to Eastward versus Southeastward Transport of Asian Dust Events
}

\author{
Fujung Tsai ${ }^{1}$ and Wei-Nai Chen ${ }^{2}$ \\ ${ }^{1}$ Department of Marine Environmental Informatics, National Taiwan Ocean University, Keelung 202, Taiwan \\ ${ }^{2}$ Research Center for Environmental Changes, Academia Sinica, Taipei 115, Taiwan \\ Correspondence should be addressed to Fujung Tsai; fujung@mail.ntou.edu.tw
}

Received 26 October 2013; Accepted 24 November 2013; Published 4 February 2014

Academic Editor: Chung-Ru Ho

Copyright (C) 2014 F. Tsai and W.-N. Chen. This is an open access article distributed under the Creative Commons Attribution License, which permits unrestricted use, distribution, and reproduction in any medium, provided the original work is properly cited.

\begin{abstract}
Asian dust events that travel eastward and southeastward in the lower troposphere affect different areas near the coastal East Asia. To understand the synoptic differences between the two types of dust events, four dust events from 2006 to 2009 are selected for each type and the synoptic environment is compared. Surface measurements, trajectory analyses, and a regional dust model are also applied to further analyze each type. Results show that the strength of the low-level trough and the surface anticyclonic system are important in determining the transport route of dust event. A deep $700-850 \mathrm{hPa}$ trough extending far south beyond $30^{\circ} \mathrm{N}$ associated with an intense surface anticyclone with maximum pressure greater than $1020 \mathrm{hPa}$ over coastal East Asia favors southeastward movement of dust event. The prevailing northwesterlies or northerlies behind the deep trough and ahead of the intense surface anticyclone promote the southeastward movement of dust event. Since intense surface anticyclones often associated with strong dust events, severe dust activities tend to move southeastward. In contrast, a shallow trough accompanied by a weak surface high locating north of $30^{\circ} \mathrm{N}$ over the coastal East Asia favors an eastward transport route.
\end{abstract}

\section{Introduction}

Asian dust is mainly generated from China during springtime, when cyclonic activity and the induced strong surface wind favor the generation of dust from the dry surface. The generated dust particles can be transported downwind over long distances $[1,2]$. The transport pathways for dust include eastward routes to Korea, Japan, and the North Pacific, as well as southeastward routes to Southeast China, Taiwan, Hong Kong, and even the South China Sea [3]. According to previous studies, the annual emissions of Asian dust can be as large as $460 \mathrm{Tg}$ to $800 \mathrm{Tg}[4,5]$, and half of the dust parcels experience long-range transport [4]. Thus, it can be expected that these long-range transport events can significantly affect the downwind areas.

Previous studies show that both eastward and southeastward transport increase aerosol concentration over the coastal areas of East and Southeast China [6-9]. During eastward transport, major dust events normally occur once or twice annually in Korea, with aerosol concentrations increasing up to $1105 \mu \mathrm{g} \mathrm{m}^{-3}$ [7]. In spring 2001, the maximum aerosol concentration of approximately $200 \mu \mathrm{g} \mathrm{m}^{-3}$ to $450 \mu \mathrm{g} \mathrm{m}^{-3}$ was observed over the coast of Japan and Korea $[10,11]$. On the other hand, during southeastward transport, concentrations of particulate matter less than $10 \mu \mathrm{m}$ in diameter $\left(\mathrm{PM}_{10}\right)$ can be enhanced over 400,600 , and $1000 \mu \mathrm{g} \mathrm{m}^{-3}$ in cities over or near Southeast China, such as Hong Kong, Xiamen, and Taiwan, respectively [12-14]. Southeastward dust events are occasionally observed reaching far south beyond $20^{\circ} \mathrm{N}$ into the South China Sea $[13,15,16]$, and the depositions were observed to enhance phytoplankton growth $[17,18]$.

The synoptic characteristics of the eastward dust event have been explored in previous studies $[2,19,20]$. Through aircraft measurement, Dickerson et al. [20] found that the eastward propagation of cyclones and associated fronts provide the mechanism for the lifting and long-range transport 
of dust, whereas behind the surface cold front, the dust parcel was lifted from the surface to approximately $4000 \mathrm{~m}$ because of the strong surface wind associated with anticyclone. Liu et al. [19] simulated an Asian dust event in 2001 and found that mechanical and convective turbulence mixed the dust particles from the surface, and the upward motion ahead of the cyclones is responsible for transporting dust to high altitudes and into the westerlies, making it available for longrange transport.

Unlike eastward transport, the synoptic environment for the southeastward transport is distinctive. Liu et al. [9] found that the major southeastward dust events from 2002 to 2006 were transported behind the lower tropospheric trough in the descending areas and descend with height to the southeastern coast of China. Yu et al. [21] also found that the southeastward transport of Asian dust is often associated with a surface anticyclone breaking away from the Siberian-Mongolian High at the high latitudes. When the surface anticyclone moves southeastward, dust can be carried to the subtropics. In these previous studies, although the synoptic environment favoring the eastward and southeastward movement of dust events is discussed, the difference between lower level transport of the two types is unclear. It is still unknown why some dust events moving near the surface layer are allowed to be transported far southeastward into the South China Sea, whereas others are transported shallower and eastward and mainly affect the East Asian midlatitudes. Tsai et al. [22] classified the transport route of dust parcel into three types, including upper-level, lower-level, and descending types. In the lower-level type, dust parcel is transported behind a lower-level trough near the surface layer where the associated surface high is intense. However, the synoptic differences between the low-level dust events that result in eastward and southeastward transport routes remain undiscussed.

To clarify this problem, this study compares the synoptic environment between the major eastward and southeastward dust events from 2006 to 2009 and investigates their differences. Four dust events that reached coastal East Asia during these years are selected for each type, and their synoptic conditions in the lower troposphere and surface level are compared. In addition, a southeastward and an eastward dust event that occurred sequentially in 2006 are selected as cases for analysis. In Section 3, the synoptic characteristics of the two types of dust event are presented and compared. In Section 4, one of each type is selected for case study and the trajectory simulation, synoptic analyses, and $3 \mathrm{D}$ regional dust simulations are used to investigate the synoptic environment favoring the two types of dust transport. The synoptic differences between the southeastward and eastward transport of dust events in the lower troposphere are summarized and concluded in Section 5.

\section{Data and Model}

2.1. Particulate Matter. The $\mathrm{PM}_{10}$ concentrations are obtained from the Wanli $\left(121.7^{\circ} \mathrm{E}, 25.2^{\circ} \mathrm{N}\right)$ and Hengchun $\left(121.8^{\circ} \mathrm{E}, 21.9^{\circ} \mathrm{N}\right)$ stations in Taiwan (Figure 1). The two stations are the Taiwan Environmental Protection

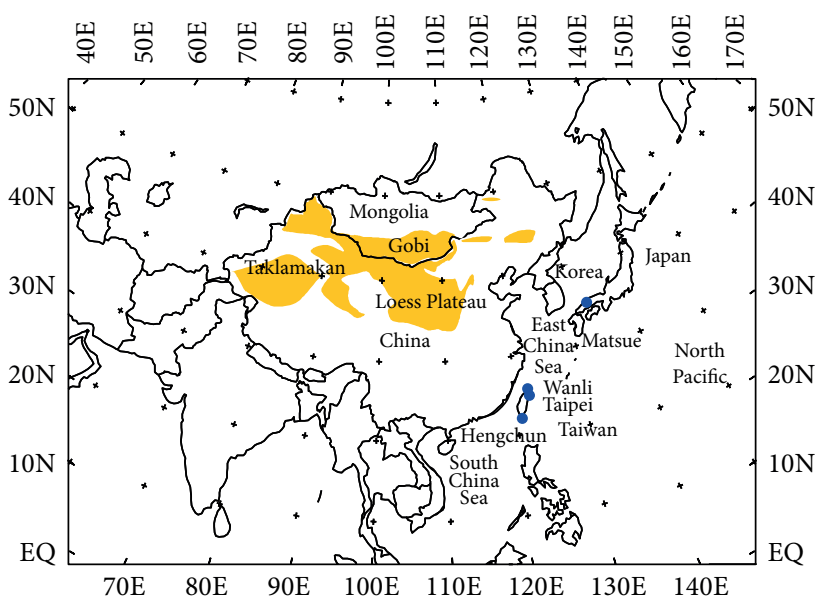

FIgURE 1: TAQM model domain and dust observation sites (blue dot) at Wanli, Taipei, and Hengchun in Taiwan and Matsue in Japan. Deserts over China are indicated by shaded areas.

Administration (EPA) stations in the northern and southern tips of Taiwan, respectively. They are commonly used to represent the background aerosol concentrations due to their locations right next to the ocean.

2.2. Lidar. The lidar measurements are obtained from Taipei $\left(121.53^{\circ} \mathrm{E}, 25.01^{\circ} \mathrm{N}\right)$, Taiwan, and Matsue $\left(133.01^{\circ} \mathrm{E}, 35.48^{\circ} \mathrm{N}\right)$, Japan (Figure 1). The Taipei lidar system is installed in the Taipei Aerosol and Radiation Observatory at the National Taiwan University, about $20 \mathrm{~km}$ from the EPA Wanli station. The system measures the vertical distribution of aerosol backscattering ( $532 \mathrm{~nm}$ and $355 \mathrm{~nm}$ ), extinction, and depolarization (at $532 \mathrm{~nm}$ ) by detecting the Rayleigh/Mie backscattering of atmospheric molecules and aerosol particles. At Matsue (Shimane Prefectural Institute of Public Health and Environmental Science), both aerosol backscattering ( $532 \mathrm{~nm}$ and $1064 \mathrm{~nm}$ ) and depolarization (at $532 \mathrm{~nm}$ ) are measured with a laser power of $20 \mathrm{~mJ}$ for both wavelengths, with a repetition rate of $10 \mathrm{~Hz}$ and telescope diameter of $20 \mathrm{~cm}$. More details on the lidar characteristics can be found in the studies by Chen et al. [23] and Shimizu et al. [24].

The lidar depolarization ratio used to identify dust particles is defined as the ratio of the returned light in perpendicular polarization to the parallel polarizations. Owing to the irregular shape of the dust particles, the intensity of the return lights between perpendicular and parallel polarization (depolarization ratio) is different for dust particles when compared with anthropogenic aerosol. A depolarization ratio greater than 0.06 is suggested for distinguishing dust particles from other type aerosol particles [25].

2.3. Meteorological Data. The National Centers for Environmental Prediction (NCEP) - National Center for Atmospheric Research (NCAR) Reanalysis [26] — is used to analyze the synoptic conditions during the dust event. The global reanalysis data have a spatial resolution of $2.5^{\circ} \times 2.5^{\circ}$ and a temporal resolution of $6 \mathrm{~h}$, including geopotential height, air 
TABLE 1: The date of selected eastward and southeastward dust events in Taiwan and Japan respectively, their peak hour at Wanli, Taiwan, and Matsue, Japan, obtained from surface or lidar measurements, their maximum $\mathrm{PM}_{10}$ concentration at northern (Wanli) and southern tip (Hengchun) of Taiwan, and number of Japanese stations that observed the dust events.

\begin{tabular}{|c|c|c|c|c|c|}
\hline Type of dust event & Observed date & $\begin{array}{l}\text { Peak hour at Taiwan } \\
\text { or Japan (UTC) }\end{array}$ & $\begin{array}{c}\text { N. Taiwan } \\
\text { maximum }\left(\mu \mathrm{g} \mathrm{m}^{-3}\right)\end{array}$ & $\begin{array}{c}\text { S. Taiwan } \\
\text { maximum }\left(\mu \mathrm{g} \mathrm{m}^{-3}\right)\end{array}$ & $\begin{array}{c}\text { Number of Japanese } \\
\text { stations with dust } \\
\text { observation }\end{array}$ \\
\hline \multirow{4}{*}{ Southeastward } & $2006 / 3 / 19-20$ & $3 / 19$ 08:00 & 268 & 136 & 10 \\
\hline & $2006 / 3 / 28-30$ & $3 / 2813: 00$ & 124 & 156 & 14 \\
\hline & 2007/1/28-29 & $1 / 2814: 00$ & 234 & 160 & 0 \\
\hline & $2009 / 4 / 25-26$ & $4 / 2506: 00$ & 1000 & 378 & 9 \\
\hline \multirow{4}{*}{ Eastward } & $2006 / 3 / 23-24$ & $3 / 2302: 00$ & 81 & 68 & 20 \\
\hline & $2006 / 4 / 24-25$ & 4/24 00:00 & 155 & 46 & 40 \\
\hline & $2007 / 5 / 26-27$ & 5/26 07:00 & 61 & 32 & 46 \\
\hline & 2009/3/17-19 & 3/17 00:00 & 80 & 34 & 41 \\
\hline
\end{tabular}

temperature, vertical velocity (omega), 3D wind field, and sea-level pressure.

2.4. Model Descriptions. The dust module in the Taiwan Air Quality Model (TAQM-Dust) is added to simulate regional dust distributions over East Asia [11, 22]. The original TAQM is a $3 \mathrm{D}$ regional model used to simulate the distribution of trace gases and particles [27]. The TAQM-Dust model domain covers East Asia from approximately $10^{\circ} \mathrm{N}$ to $60^{\circ} \mathrm{N}$ and $60^{\circ} \mathrm{E}$ to $140^{\circ} \mathrm{E}$ (Figure 1), with a horizontal resolution of $81 \mathrm{~km}$. Vertically, the model is divided into 15 sigma levels, with vertical resolution ranging from roughly $40 \mathrm{~m}$ near the surface to $1 \mathrm{~km}$ to $2 \mathrm{~km}$ near the tropopause of $100 \mathrm{hPa}$. During dust seasons, dust particles can have a residence time of more than a week in the model domain. Thus, a 10-day simulation of the model is performed ahead of the selected episode, and the subsequent simulation is used for analyses.

For the calculation of dust transport, meteorological data used as an input to the dust model are obtained from NCAR/Penn State Mesoscale Meteorological Model (MM5) [28-30] simulations. Initial and boundary conditions for MM5 are obtained from the European Center for MediumRange Weather Forecast (ECMWF) Tropical Ocean and Global Atmosphere advanced analysis.

A dust module, including emission, transport, and depositions of dust, has been incorporated into TAQM. The dust emission module was developed based on Wang et al. [31]. In the emission module, the dust particles are divided into 12 size bins ranging from $0.13 \mu \mathrm{m}$ to $20.13 \mu \mathrm{m}$. Dust transport is computed using the Bott [32] scheme, which minimizes the problem of numerical diffusion. Dust removal by wet and dry deposition, including gravitational settling of dust particle above the surface layer, is included in the dry deposition processes.

\section{Synoptic Characteristic of the Two Types}

To compare the synoptic difference between the eastward and southeastward dust event, eight major dust events of the two types from 2006 to 2009 are selected and the lower tropospheric and surface maps of the events are compared. Table 1 lists the eight dust events. Among these events, four southeastward events reached southern Taiwan, with maximum $\mathrm{PM}_{10}$ concentrations of more than $130 \mu \mathrm{g} \mathrm{m}^{-3}$, greater than that of any other event. The first (19-20 March 2006) and the fourth (25-26 April 2009) dust events are the two severe dust events during the recent decades. On the other hand, four eastward events are selected because a maximum number of surface stations (around 40 stations) in Japan observed the dust events (http://www.data.kishou.go.jp/obsenv/kosahp/kosa_data_index.html), except for the first dust event on March 2006. The first eastward event was observed by 20 surface stations, slightly less than other selected eastward events. It is selected because it occurs immediately after the first southeastward dust event on 19-20 March 2006. Thus the two continuous dust events are used as cases for comparison.

Figure 2 shows the synoptic map of the southeastward and eastward dust events at $700 \mathrm{hPa}$, an altitude where lowlevel dust events are usually located $[9,25]$. When the associated cyclone and the trough of the dust event move over the east coast of Asia, the southward extension of the trough of the southeastward dust events reaches far south beyond $30^{\circ} \mathrm{N}$ and often approaches Taiwan. As a result of the deep trough, the $3060 \mathrm{gpm}$ isopleths over the coastline are located south of $30^{\circ} \mathrm{N}$. By contrast, the southward extension of the trough of eastward event only approached south of Japan, reaching close to $30^{\circ} \mathrm{N}$. The $3060 \mathrm{gpm}$ isopleths of the eastward events mostly locate north of $30^{\circ} \mathrm{N}$ over the coastline, except for the first eastward event (Figure 2(e)). The deep and shallow trough promotes southeastward and eastward transport of dust events out of the coastal East Asia, respectively.

Figure 3 shows the surface map for the two types of dust events. The surface anticyclonic circulation of the southeastward dust event covers a wide area of the eastern coast of China, with a maximum pressure often greater than $1020 \mathrm{hPa}$. Compared with the southeastward event, the synoptic pattern for the eastward event is distinctive. The associated cyclonic circulation is strong over Mongolia and northern China, whereas the anticyclonic circulation is often weak, covering only a small area of the eastern coast, with a maximum 


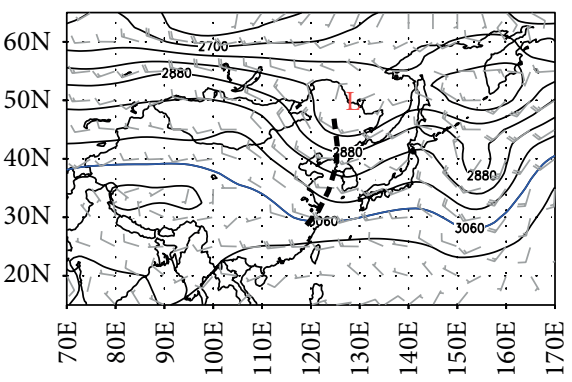

(a) 00 UTC 18 March 2006

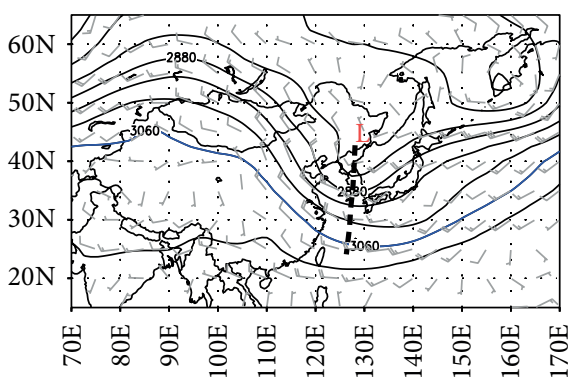

(b) 00 UTC 28 March 2006

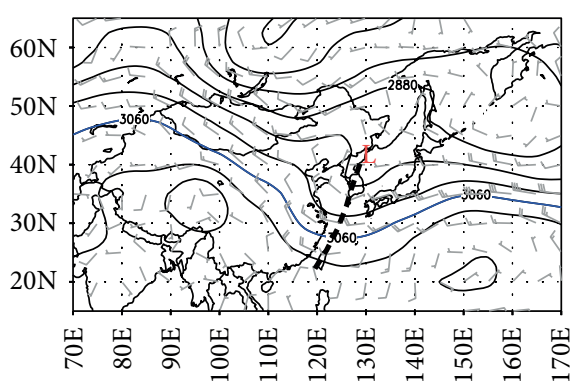

(c) 00 UTC 28 January 2007

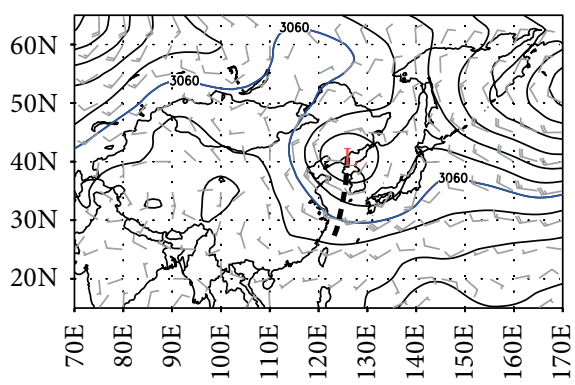

(d) 00 UTC 25 April 2009

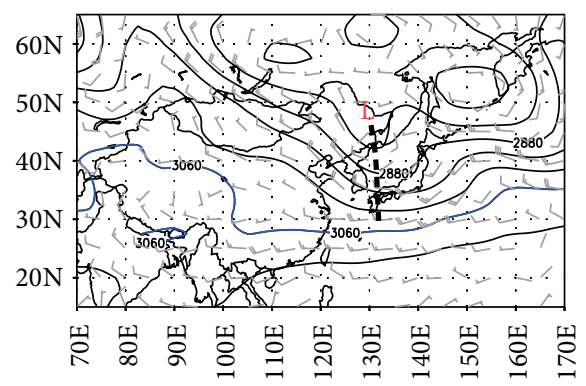

(e) 00 UTC 23 March 2006

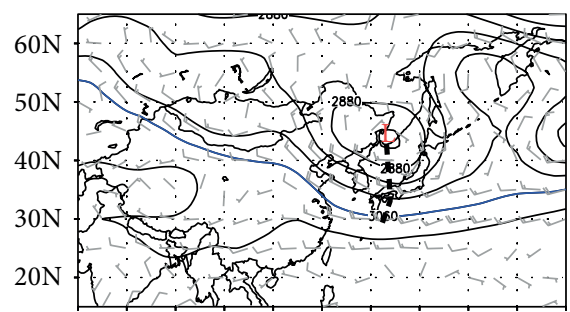

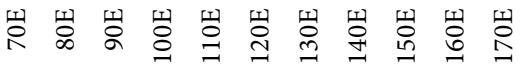

(f) 00 UTC 24 April 2006

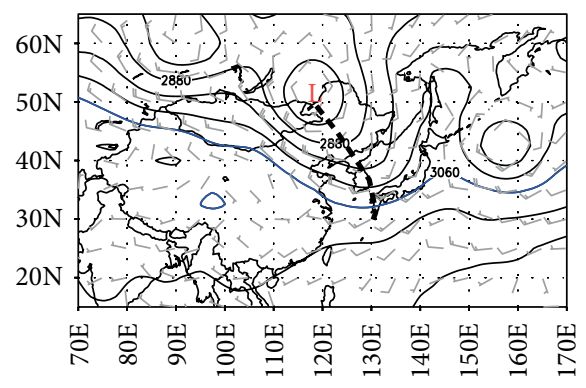

(g) 00 UTC 25 March 2007

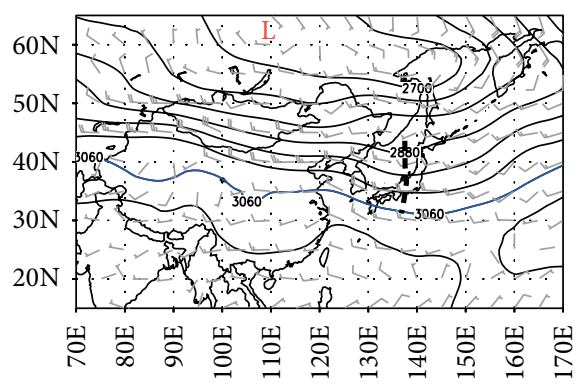

(h) 18 UTC 16 March 2009

FIGURE 2: $700 \mathrm{hPa}$ synoptic maps for the (a)-(d) southeastward and (e)-(h) eastward dust events. The full barb and half barb represent 10 and $5 \mathrm{~m} \mathrm{~s}^{-1}$, respectively. Geopotential heights (gpm, solid lines) are analyzed at 60 gpm intervals.

pressure of less than $1020 \mathrm{hPa}$. The strong cyclonic and weak anticyclonic circulation is favorable for zonally transport of dust events.

Previous study also indicates that the surface condition of cyclonic and anticyclonic systems over the source areas is important in determining the strength or transport pathway of dust activity $[26,33]$. When the surface anticyclone is greater than $1040 \mathrm{hPa}$ during dust generation, dust event is often transported in the lower troposphere because of the strong descending motion of the anticyclonic circulation [26]. In addition, if surface pattern exhibits a low-high dipole orienting in northeast-southwest direction over the source areas, the dust activity is more active [33]. In this study, the surface synoptic map of the southeastward dust events is mostly dominated by the intense high-pressure system and similar low-high dipole. Two of the selected southeastward events are also the severest dust events in recent years. Thus, an intense surface high accompanied with active dust activity 


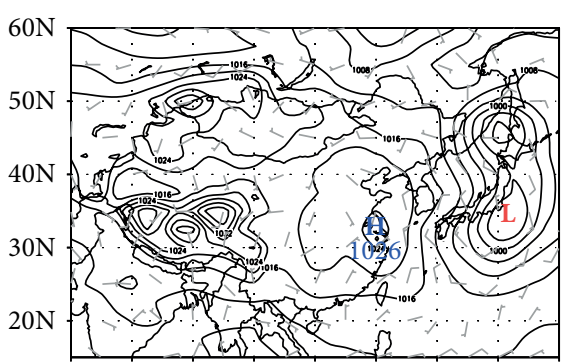

$70 \mathrm{E}$ 80E 90E 100E 110E 120E 130E 140E 150E

(a) 00 UTC 19 March 2006

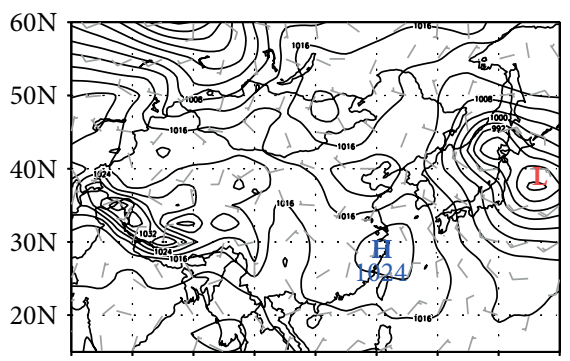

$70 \mathrm{E} \quad 80 \mathrm{E}$ 90E $100 \mathrm{E} 110 \mathrm{E} 120 \mathrm{E} 130 \mathrm{E} 140 \mathrm{E} 150 \mathrm{E}$

(b) 00 UTC 29 March 2006

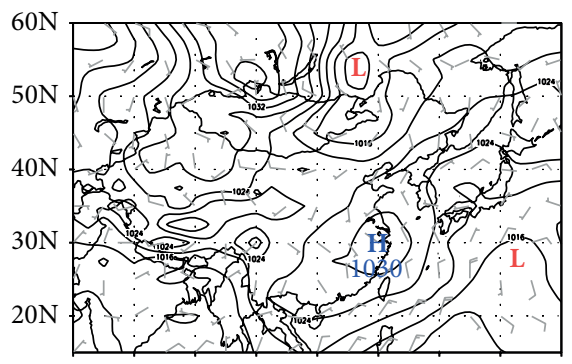

$70 \mathrm{E} \quad 80 \mathrm{E}$ 90E $100 \mathrm{E} 110 \mathrm{E} 120 \mathrm{E} 130 \mathrm{E} 140 \mathrm{E} 150 \mathrm{E}$

(c) 12 UTC 28 January 2007

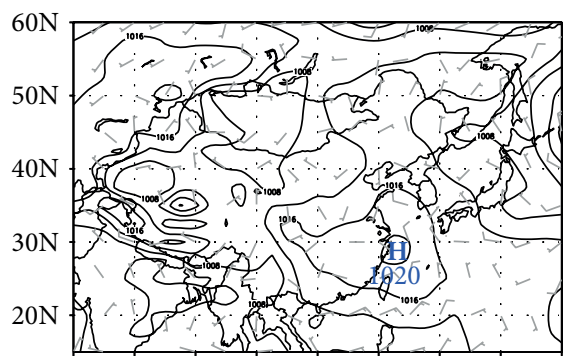

$70 \mathrm{E} \quad 80 \mathrm{E}$ 90E $100 \mathrm{E} 110 \mathrm{E} 120 \mathrm{E} 130 \mathrm{E} 140 \mathrm{E} 150 \mathrm{E}$ (d) 12 UTC 27 April 2009

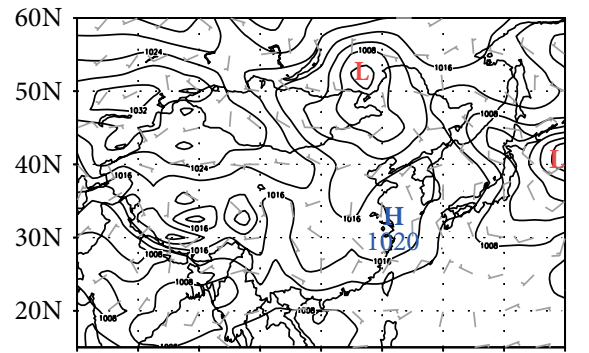

70 E $80 \mathrm{E}$ 90E 100E 110E 120E 130E 140E 150E

(e) 18 UTC 23 March 2006

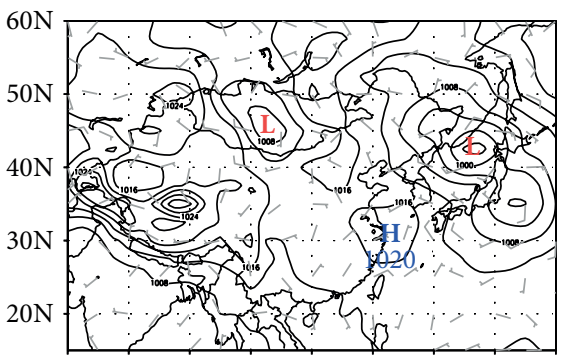

$70 \mathrm{E} \quad 80 \mathrm{E} \quad 90 \mathrm{E}$ 100E 110E 120E 130E 140E 150E

(f) 00 UTC 24 April 2006

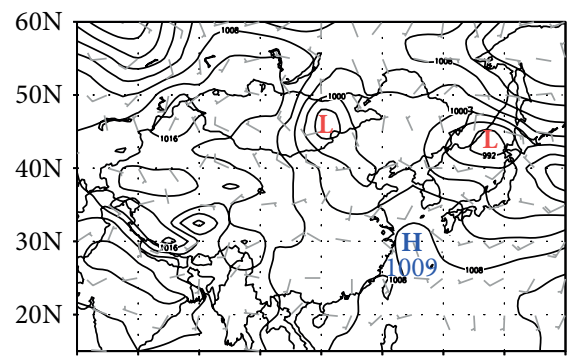

$70 \mathrm{E}$ 80E 90E 100E 110E 120E 130E 140E 150E

(g) 06 UTC 26 May 2007

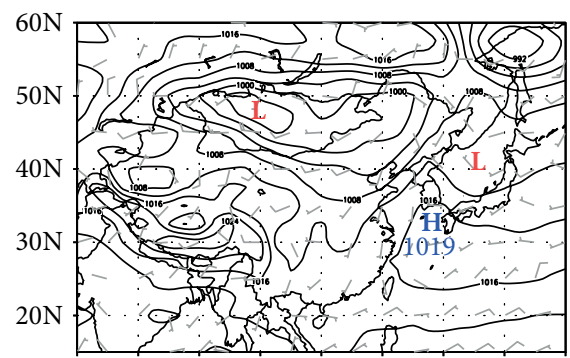

$70 \mathrm{E} \quad 80 \mathrm{E}$ 90E 100E 110E 120E 130E 140E 150E

(h) 18 UTC 16 March 2009

FIGURE 3: Surface weather maps for the (a)-(d) southeastward and (e)-(h) eastward dust events. The full barb and half barb represent 10 and $5 \mathrm{~m} \mathrm{~s}^{-1}$, respectively. Sea-level pressure is analyzed at $4 \mathrm{hPa}$ intervals.

generated by the strong surface winds potentially favors southeastward transport route.

\section{Case Study}

4.1. First Events of the Two Types. To illustrate further the difference in the synoptic environment between the two types of dust events, the first event of each type is selected for case study. The selected southeastward dust event occurred on
16-20 March 2006, with observed $\mathrm{PM}_{10}$ concentration reaching more than $268 \mu \mathrm{g} \mathrm{m}^{-3}$ in the northern tip of Taiwan (Table 1) and approaching $400 \mu \mathrm{g} \mathrm{m}^{-3}$ over Taipei city. Following this event, the eastward dust event was observed on 22-24 March over Japan by 20 surface stations.

Figure 4 shows the vertical profile of the total depolarization ratios of lidar measured at Taipei, Taiwan, and Matsue, Japan, and compares with model results. For the southeastward-moving dust event, the dust clouds are observed 


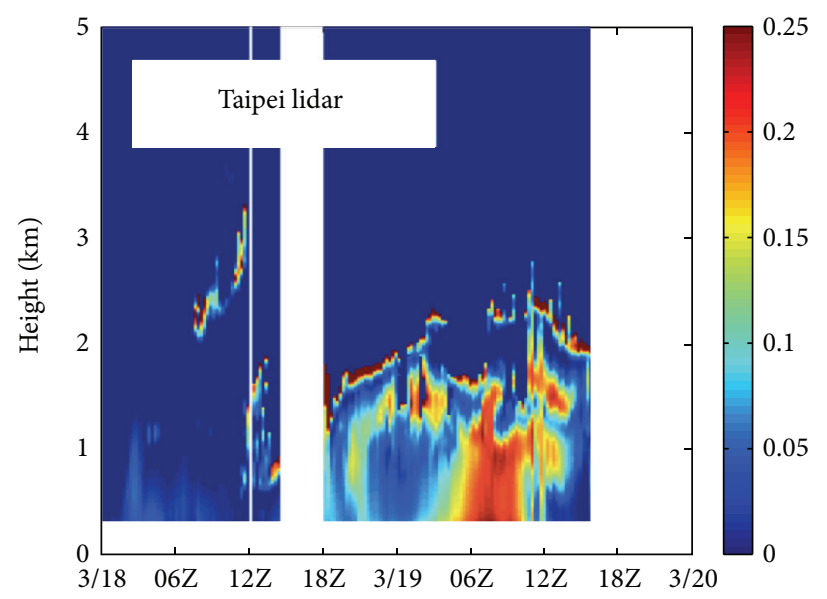

(a)

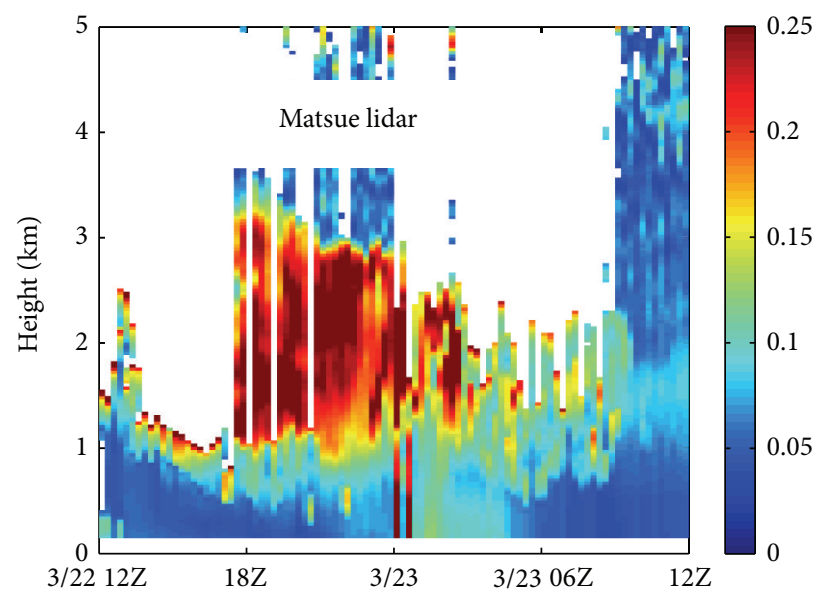

(b)

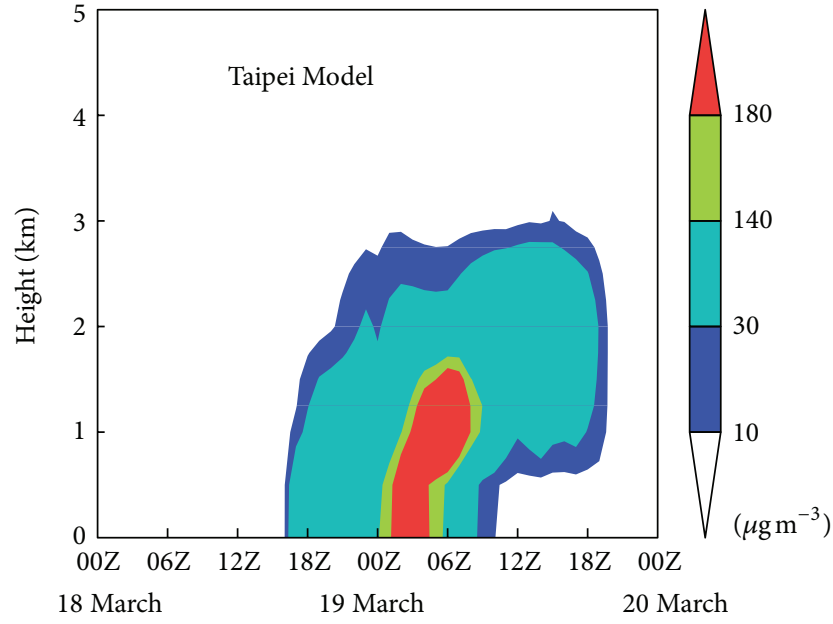

(c)

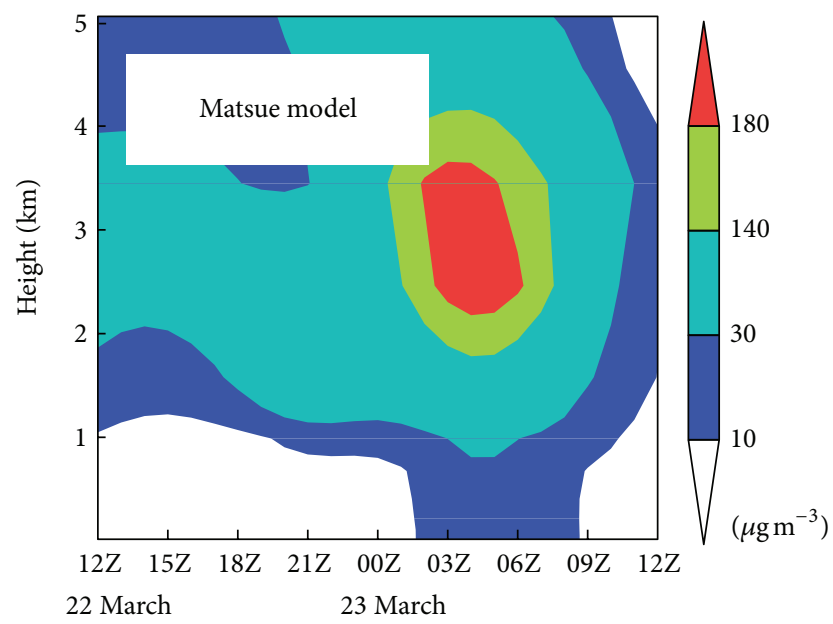

(d)

FIGURE 4: Vertical distributions of dust observed by lidar total depolarization ratio ( $>0.06$ indicates dust) for the (a) southeastward event at Taipei, Taiwan, on 18-20 March and (b) eastward event at Matsue, Japan, on 22-23 March and compared with model simulation at (c) and (d), respectively.

at Taipei on 19 March, with dust concentrations remaining mostly below $1.5 \mathrm{~km}$ (Figure 4(a)). For the eastward dust event, lidar results show that the dust events peak from $1 \mathrm{~km}$ to $3 \mathrm{~km}$ on late 22 March to early 23 March and descend to the surface layer on early 23 March at Matsue (Figure 4(b)).

For model verification, Figure 4 also shows the model simulation of dust profiles at the same time and locations of the two dust events in comparison with the lidar observations. At both stations, the simulated peak concentrations mostly concur with the lidar measurements. However, small discrepancies are also found. For example, the simulated peak concentration in Taipei occurs at 0300 UTC on 19 March, which is $4 \mathrm{~h}$ earlier than observation (Figure $4(\mathrm{c})$ ). In Matsue, the model results may underpredict the dust concentration on late 22 March and predict the maximum concentration from around $2.5 \mathrm{~km}$ to $4 \mathrm{~km}$, instead of $1 \mathrm{~km}$ to $3 \mathrm{~km}$ on early 23 March (Figure 4(d)). The discrepancy has resulted from meteorological simulations, which produce slightly faster southeastward transport and higher eastward transport during dust events compared with actual situation.

Figure 5 shows the backward trajectories of the two events obtained from the National Oceanic and Atmospheric Administration (NOAA) Hybrid Single Particle Lagrangian Integrated Trajectory (HYSPLIT) website (http:// www.ready.noaa.gov/) [34]. The two trajectories originated from Taipei (0800 UTC 19 March) and Matsue (0200 UTC 23 March) at the hour of maximum concentrations. The initial heights of the trajectory for Taipei $(200,500$, and $800 \mathrm{~m}$ ) and Matsue $(1700,2000$, and $2300 \mathrm{~m}$ ) are every $300 \mathrm{~m}$ within altitudes where high dust concentrations are observed by lidar. Backward trajectories were performed for four days. Result shows that the southeastward dust event passes through deserts of China on 16-17 March 2006 and moves southeastward toward Taiwan during downwind transport. Following this event, the eastward event passes through the 


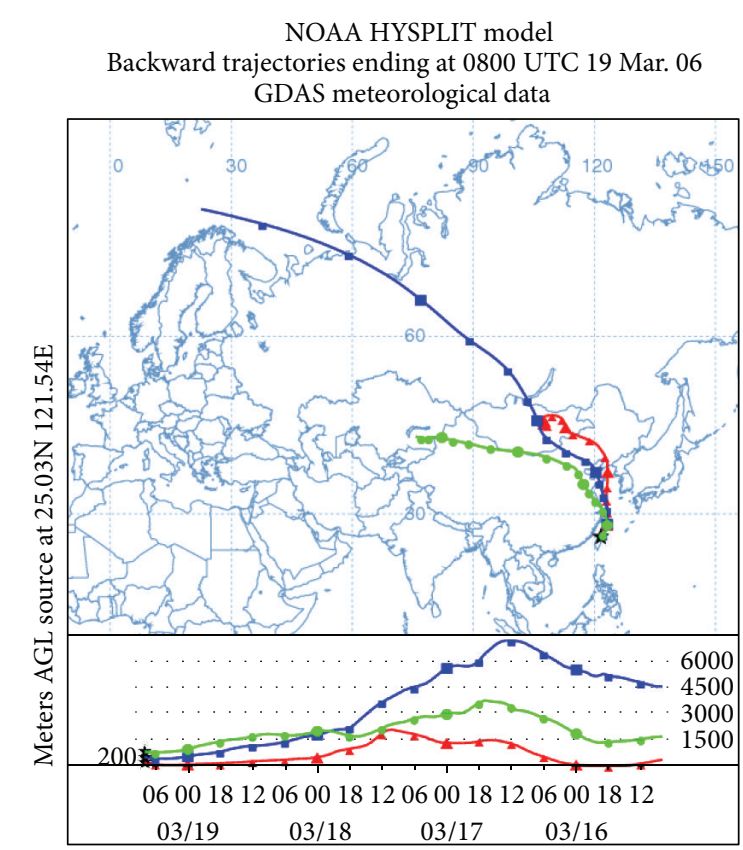

(a)

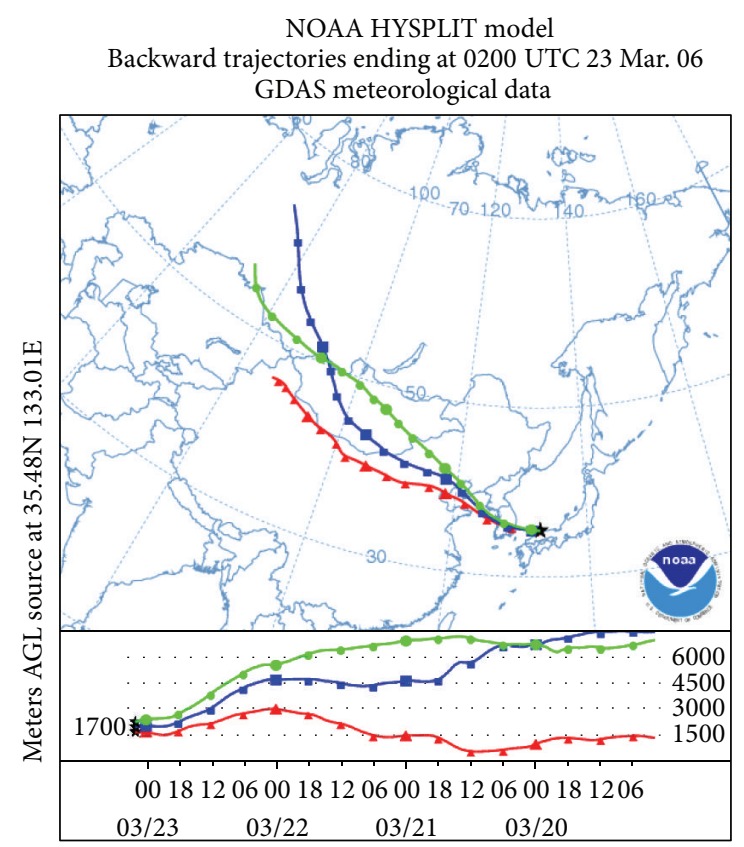

(b)

FigURE 5: NOAA HYSPLIT backward trajectories of (a) southeastward and (b) eastward dust events and their vertical profiles initiated from Taipei, Taiwan, and Matsue, Japan, respectively. Initial heights are 200, 500, and $800 \mathrm{~m}$ for the southeastward event and 1700, 2000, and 2300 $\mathrm{m}$ for the eastward event. Trajectories are marked every 6 hours.

deserts in Mongolia and northern China on 20-21 March but moves eastward downwind to Japan.

Figure 6 analyzes the atmospheric circulation at 500, 700, and $850 \mathrm{hPa}$, following the downwind transport of the southeastward dust event. The lowest-level trajectories predicted by the HYSPLIT trajectory model in Figure 5 are added in Figure 6, so the movement of the dust parcels toward the downwind areas can be better identified. Figure 6 shows that the southeastward dust event is initiated at around $16 \mathrm{March}$, when simulated dust cloud is concentrated over northern and western China in the lower troposphere (Figure 6(c)). After initiation of the dust event, some dust particles are mixed upward from the ground and travel in the free troposphere. At this time, a $500 \mathrm{hPa}$ trough moves across the western border of Mongolia and China on 16 March (Figure 6(a)), and a short wave $700 \mathrm{hPa}$ trough (heavy dash line) is located in southern Mongolia (Figure 6(b)). Behind the trough, the northwesterly winds associated with cold advection prevail, leading to the development of the trough.

Figure 6 also shows that the traced dust parcel (square with $\mathrm{x}$ ) is located among the dust clouds generated ahead of the trough (heavy dash line) and is uplifted to $700 \mathrm{hPa}$ due to ascending motion (heavy solid line). Note that the dust parcel identified by the backward trajectory is located at $770 \mathrm{hPa}$, which is close to $700 \mathrm{hPa}$. Likewise, the synoptic maps for the closest pressure level of the dust parcel are analyzed in this study.

On $18 \mathrm{March}$, as the intensified trough moves away from the eastern coast of China, the $500 \mathrm{hPa}$ trough lags the trough in the lower troposphere and the resulting strong cold advection behind the trough favors the intensification of the trough (Figures 6(e) and 6(f)), resulting in the deepening and intensification of the trough. The $700 \mathrm{hPa}$ to $850 \mathrm{hPa}$ trough extends from northeastern China at around $50^{\circ} \mathrm{N}$ southward beyond $30^{\circ} \mathrm{N}$ because of the deepening of the trough. Thus, the prevailing wind becomes approximately northerly behind the $850 \mathrm{hPa}$ trough (Figure 6(f)). Following the strong prevailing northerlies, substantial dust clouds follow the traced dust parcels, turning from mainly eastward to almost southward toward the low latitudes of Southeast China. Along the southward transport, the traced dust parcels also descend rapidly from around $700 \mathrm{hPa}$ to $850 \mathrm{hPa}$ because of the sinking motion of the northerlies behind the deep trough. Figure 6(f) and other similar figures in Figures 6 to 7 also show that the traced dust parcels are located right over the simulated dust clouds when traveling downwind. The result indicates the consistency between the trajectory and the regional model simulation.

On 19 March, the traced dust parcels move almost southward toward northern Taiwan (Figure 6(i)). At this time, the northerly or northwesterly winds remain strong over northern Taiwan. Thus, the low-level dust clouds keep moving southward, passing Taiwan toward the South China Sea in the next two days.

Following the passage of the southeastward dust event, the eastward transport dust event occurs two days later in northern China. The dust event is initiated at 0600 UTC on 


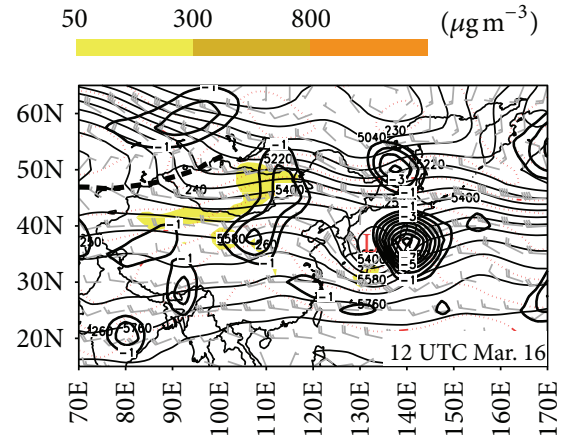

(a) $500 \mathrm{hPa}$

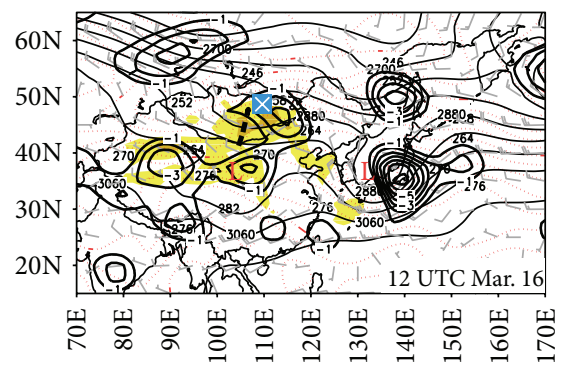

(b) $700 \mathrm{hPa}$

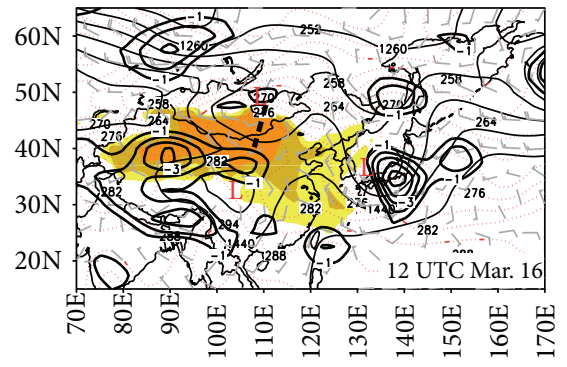

(c) $850 \mathrm{hPa}$

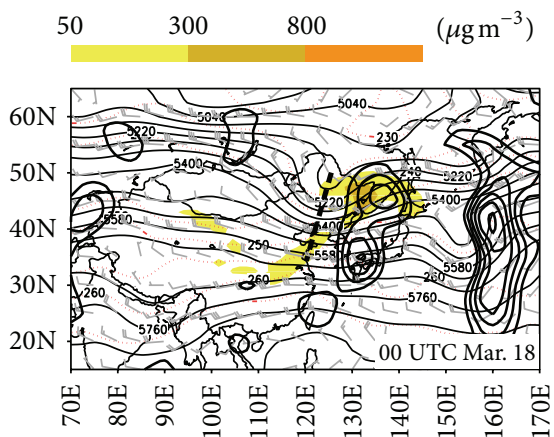

(d) $500 \mathrm{hPa}$

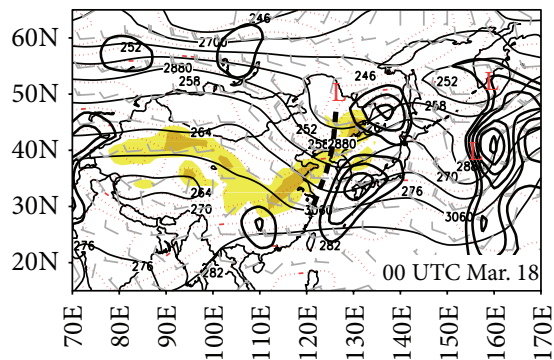

(e) $700 \mathrm{hPa}$

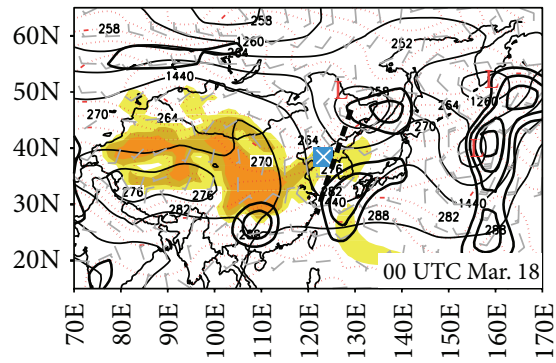

(f) $850 \mathrm{hPa}$

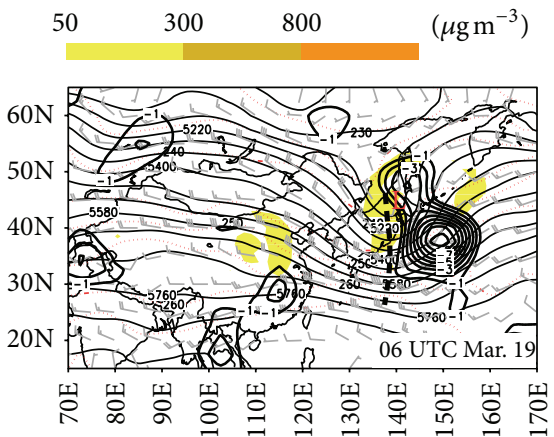

(g) $500 \mathrm{hPa}$

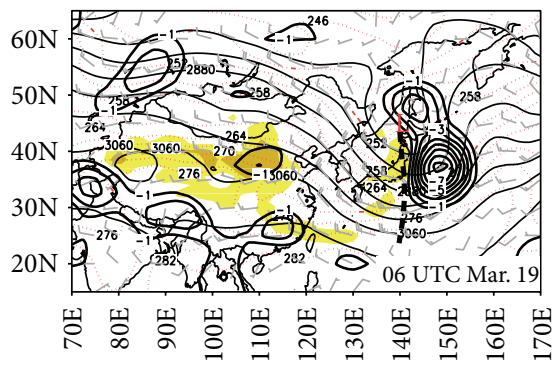

(h) $700 \mathrm{hPa}$

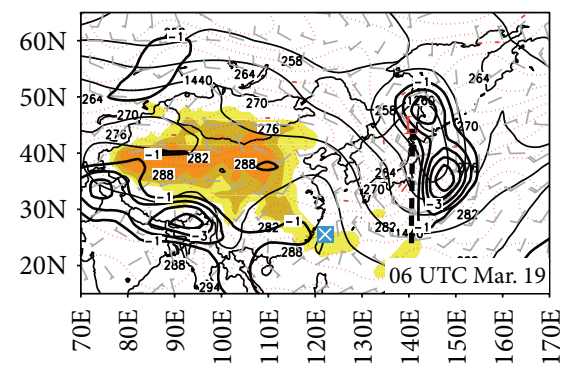

(i) $850 \mathrm{hPa}$

Figure 6: Synoptic maps for southeastward event at $500 \mathrm{hPa}, 700 \mathrm{hPa}$, and $850 \mathrm{hPa}$ of (a)-(c) 1200 UTC on $16 \mathrm{March}$, (d)-(f) $0000 \mathrm{UTC}$ on $18 \mathrm{March}$, and (g)-(i) 0600 UTC on 19 March, respectively. The full and half barbs represent 10 and $5 \mathrm{~m} \mathrm{~s}^{-1}$, respectively. Geopotential heights (solid lines) are analyzed at $60 \mathrm{gpm}$ intervals. Temperatures (dot line) are analyzed at $5^{\circ} \mathrm{C}$ intervals at $500 \mathrm{hPa}$ and $3^{\circ} \mathrm{C}$ intervals at others. Upward motion (heavy solid lines) is analyzed at $10 \mathrm{~Pa} \mathrm{~s}^{-1}$ intervals. Dust parcels identified by trajectory model (square with $\mathrm{x}$ ), upper-level troughs (heavy dash line), and simulated dust concentrations (shaded) are plotted.

21 March when a $500 \mathrm{hPa}$ shortwave trough moves over Mongolia (Figure 7(a)). At $700 \mathrm{hPa}$, the northwesterlies behind the trough prevail, and the cold advection supports the development of the trough (Figure 7(b)). Near the southern end of the $700 \mathrm{hPa}$ trough, the traced dust parcel in the lowest level of Figure 5(b) is generated among the dust clouds due to strong surface winds during dust generation. After mixing and rising upward to $700 \mathrm{hPa}$, the traced dust parcel continues to move slightly upward in response to weak ascending motion (heavy solid lines) near the cyclone center. It then ascends for about half a day before descending behind the trough in the next day (also see Figure 5(b)).

About one day later, the associated trough has moved toward the eastern coast of China (Figures $7(d)-7(f)$ ). The cold advection is strong behind the trough in the lower troposphere (Figures 7(e) and 7(f)), leading to further trough development. The trough extends southward in the midlatitudes to about $35^{\circ} \mathrm{N}$ (Figures $7(\mathrm{~d})-7(\mathrm{f})$ ). The traced dust parcel, located behind the trough where northwesterlies prevail, travels mainly eastward and slightly southward, remaining at around $40^{\circ} \mathrm{N}$ (Figure $7(\mathrm{e})$ ). At the same time, some dust clouds at the higher altitudes $(500 \mathrm{hPa}$ to $700 \mathrm{hPa})$ travel eastward ahead of the trough in ascending areas. Similar to many high-level transport events, these ascending dust clouds travel eastward under the prevailing westerlies and affect the areas further downwind.

On $23 \mathrm{March}$, when the trough nearly moves from the eastern coast of China, the trough slightly deepens and extends southeastward to Japan and the western North Pacific, reaching about $30^{\circ} \mathrm{N}$ (Figures $7(\mathrm{~g})-7(\mathrm{i})$ ). At this time, northwesterlies prevail behind the trough. Following the prevailing wind, the dust clouds together with the traced dust parcel 


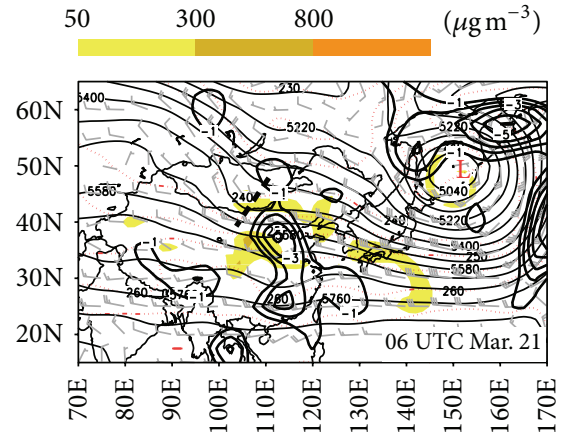

(a) $500 \mathrm{hPa}$

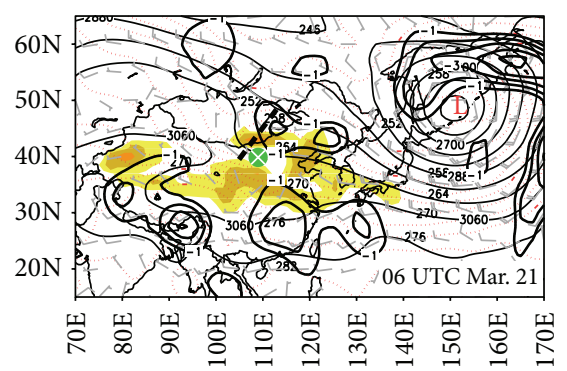

(b) $700 \mathrm{hPa}$

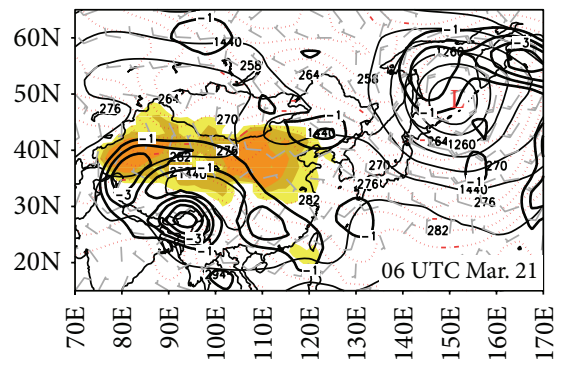

(c) $850 \mathrm{hPa}$

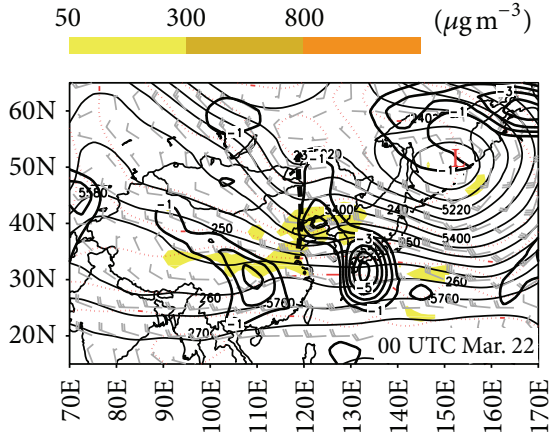

(d) $500 \mathrm{hPa}$

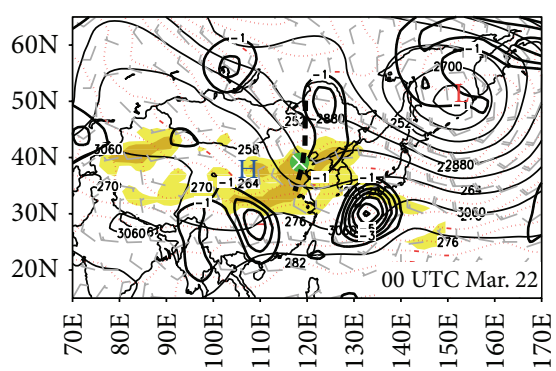

(e) $700 \mathrm{hPa}$

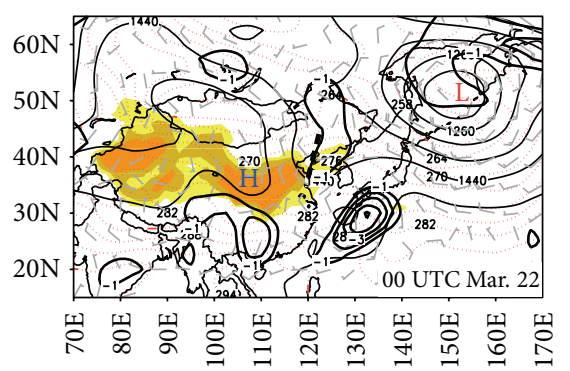

(f) $850 \mathrm{hPa}$

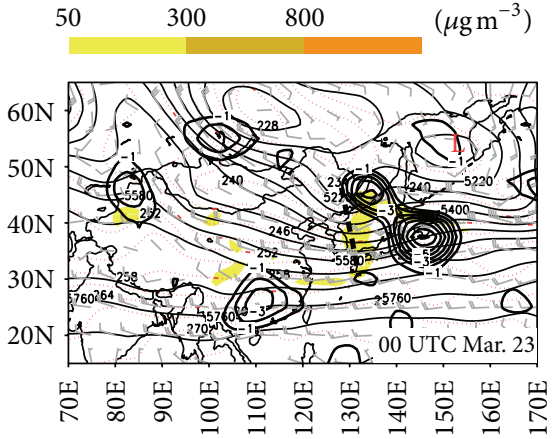

(g) $500 \mathrm{hPa}$

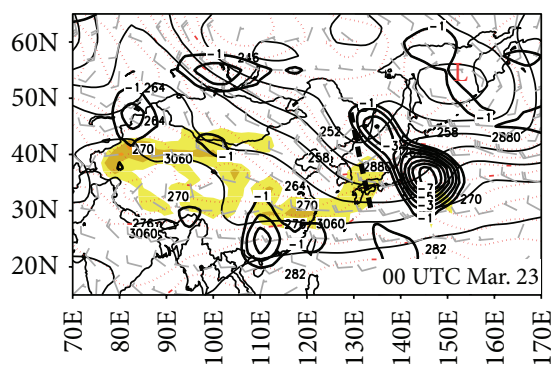

(h) $700 \mathrm{hPa}$

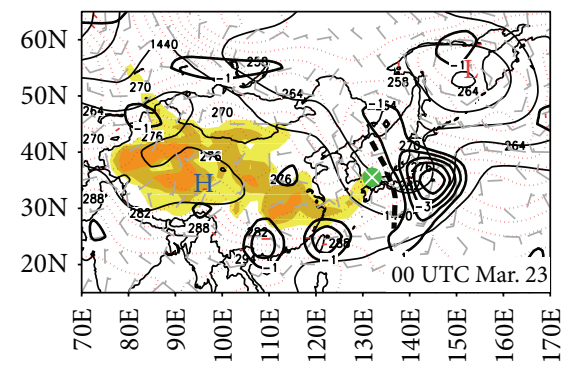

(i) $850 \mathrm{hPa}$

FIgURE 7: As in Figure 6, but for eastward dust event at 500, 700, and $850 \mathrm{hPa}$ of (a)-(c) 0600 UTC on 21 March, (d)-(f) 0000 UTC on 22 March, and (g)-(i) of 0000 UTC on 23 March, respectively.

move slightly southeastward downwind toward Japan, in which the traced dust parcel also sinks to $850 \mathrm{hPa}$ due to the descending motion behind the trough.

After leaving the continent, both the southeastward and eastward transport events pass through Taiwan and Japan and dissipate over the marginal sea of the western North Pacific Ocean. Figure 8 shows the model results of the dust events at this stage. During the southeastward movement, the surface cold front passes over Taiwan on 19 March (Figure 8(a)). Behind the cold front, the surface anticyclone has moved from Mongolia to Shanghai city (about $121^{\circ} \mathrm{E}, 31^{\circ} \mathrm{N}$ ) at the same time. The anticyclonic circulation covers most of the eastern coast, reaching as far as southern Taiwan $\left(23^{\circ} \mathrm{N}\right)$. Owing to the circulation to the east of the surface high, the prevailing winds are almost northerlies in the lower troposphere offshore of China. The dust clouds, with concentrations up to $300 \mu \mathrm{g} \mathrm{m}^{-3}$ at the southern rim of the surface high, follow the prevailing northerlies and move southward along the Asian continent. Due to the rapid movement of the surface anticyclone and strong surface winds (up to $15 \mathrm{~m} \mathrm{~s}^{-1}$ ), the dust clouds quickly move past northern Taiwan toward the South China Sea (Figure 8(b)).

On 21 March, as the surface anticyclone (about $138^{\circ} \mathrm{E}$, $26^{\circ} \mathrm{N}$ ) moves offshore to the North Pacific, the wind speeds to the southwest of the anticyclone decrease to approximately $5 \mathrm{~m} \mathrm{~s}^{-1}$, resulting in a deceleration in dust transport over the area (Figure $8(\mathrm{~b})$ ). At the same time, the prevailing easterlies to the south of the surface high-pressure system circulate the dust clouds back toward the eastern coast of the continent (Figure $8(\mathrm{~b})$ ). After the passage of the surface anticyclone on 21 March, the dust clouds remain around southern Taiwan and the northern South China Sea, with concentrations up to $140 \mu \mathrm{g} \mathrm{m}^{-3}$ reaching as far south as $20^{\circ} \mathrm{N}$.

For the eastward dust event, the dust clouds move off the eastern coast behind the associated surface front on $23 \mathrm{March}$ (Figure 8(c)), with concentrations up to $300 \mu \mathrm{g} \mathrm{m}^{-3}$ extending from southern Japan to northern Taiwan. At this time, the weak surface anticyclone remains over eastern China 


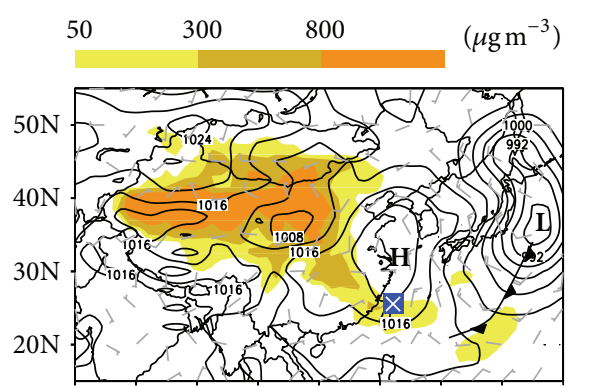

$70 \mathrm{E} \quad 80 \mathrm{E}$ 90E 100E 110E 120E 130E 140E 150E

(a) 0600 UTC 19 March

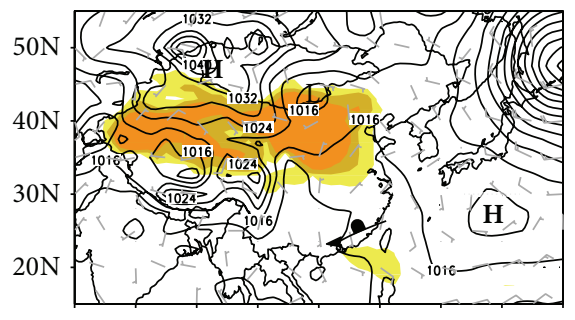

$70 \mathrm{E}$ 80E 90E 100E 110E 120E 130E 140E 150E

(b) 0000 UTC 21 March

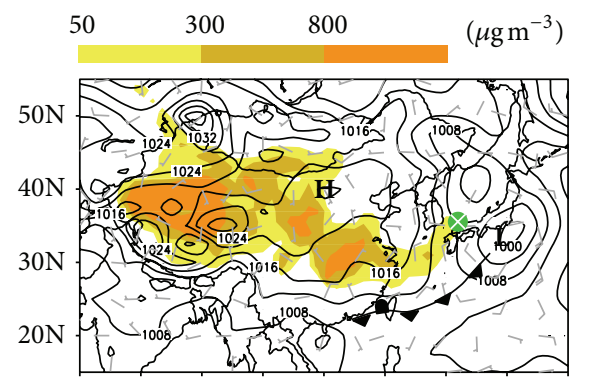

$70 \mathrm{E} \quad 80 \mathrm{E}$ 90E 100E 110E 120E 130E 140E 150E

(c) 0000 UTC 23 March

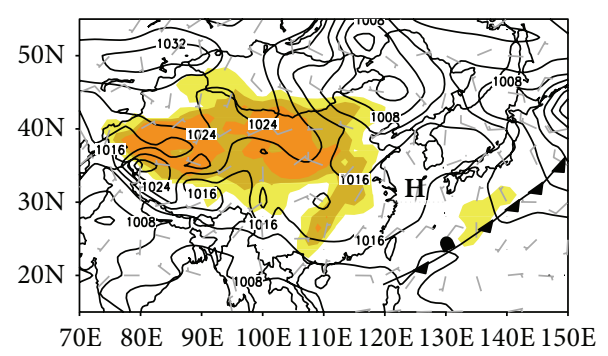

(d) 0000 UTC 24 March

FIGURE 8: Surface maps and simulated dust distributions for the southeastward event at (a) 0600 UTC on 19 March and (b) 0000 UTC on 21 March and eastward event at (c) 0000 UTC on 23 March and (d) 0000 UTC on 24 March. Sea-level pressure is analyzed at 4 hPa interval. The full and half barbs represent 10 and $5 \mathrm{~m} \mathrm{~s}^{-1}$, respectively. The traced dust parcels predicted by the trajectory model are marked (circle or square with $\mathrm{x}$ ).

(around $40^{\circ} \mathrm{N}$ ), far behind the offshore dust clouds, whereas the leading front becomes almost stationary over central Taiwan. Under the slower system, the dust clouds persist over the midlatitudes behind the front. As a result, high dust concentrations are distributed over Southeast China and the East China Sea instead of moving southeastward. One day later (Figure $8(d)$ ), when the surface anticyclone moves southeastward over Shanghai city, some dust clouds with concentration up to $200 \mu \mathrm{g} \mathrm{m}^{-3}$ already move eastward to the south of Japan away from the anticyclonic circulation, while other dust clouds behind the anticyclone remain over Southeast China. At the same time, the surface wind over the dust clouds decreases to less than $5 \mathrm{~m} \mathrm{~s}^{-1}$. Under the weak anticyclonic circulation and the slow system, the dust residual slowly dissipates over the nearby areas in the midlatitudes.

4.2. Other Events of the Two Types. Similar to the first events of the two types, the synoptic map and the trajectories for the rest of the dust events are analyzed. The trajectories started from Wanli, the northern tip of Taiwan, for the southeastward event and Matsue, Japan, for the eastward events, with altitudes originating from $200 \mathrm{~m}, 500 \mathrm{~m}$, and $800 \mathrm{~m}$, similar to the first dust events. The maximum observed dust concentration or lidar measurement from the two stations (Table 1) is traced forward or backward until the locations of the traced dust parcel relative to the lower tropospheric and surface maps that discussed in Figures 2 and 3 are found, except $850 \mathrm{hPa}$ instead of $700 \mathrm{hPa}$ in Figure 2 is used as the low tropospheric map. Dust parcel originating from $800 \mathrm{~m}$ is plotted at $850 \mathrm{hPa}$ because this is the closest level of the dust parcel, while dust parcel originating from $200 \mathrm{~m}$ is plotted on the surface map.

Figure 9 shows the traced dust parcel relative to the $850 \mathrm{hPa}$ and surface synoptic map over the coastal East Asia for the southeastward and eastward dust events. At $850 \mathrm{hPa}$, although the traced dust parcels of the two events are all located behind the trough, the traced dust parcel of the southeastward event reaches far south behind the deep trough while the traced dust parcel of the eastward event remains in the midlatitudes. At surface, the results show that the dust parcels of the southeastward events all locate south of the strong surface anticyclone near Southeast China while the parcels of the eastward events all remain between the surface cyclone and anticyclone over Japan, a result consistent with the study of the first event of the two types.

\section{Conclusions}

This study contrasts two types of Asian dust events during 2006-2009 to understand the synoptic environment that favors a substantial southeastward and eastward transport of Asian dust off the coastal East Asia. The synoptic maps, lidar observations, and a dust model simulation are applied for the analyses. The results show that the synoptic environments in the lower troposphere and surface levels are important factors resulting in difference between southeastward and eastward transports of the dust event and are summarized as follows. 


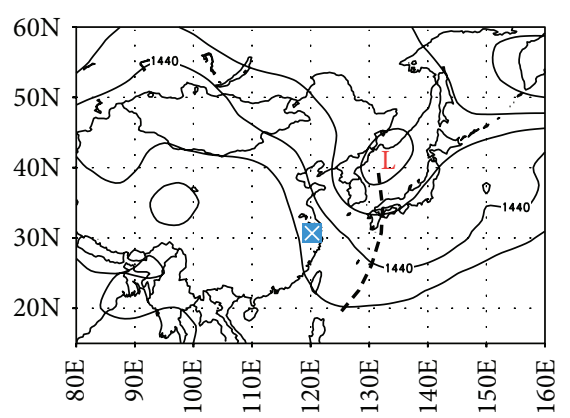

(a) 00 UTC 28 March 2005

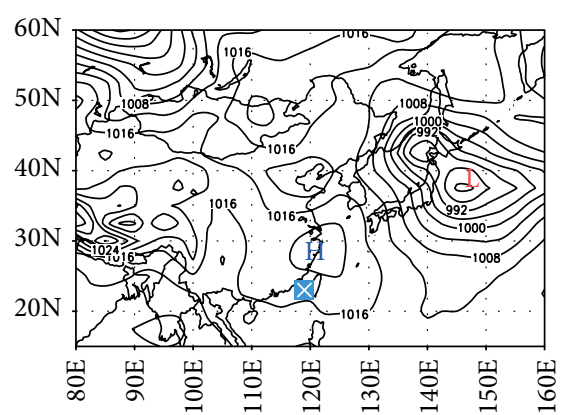

(d) 00 UTC 29 March 2006

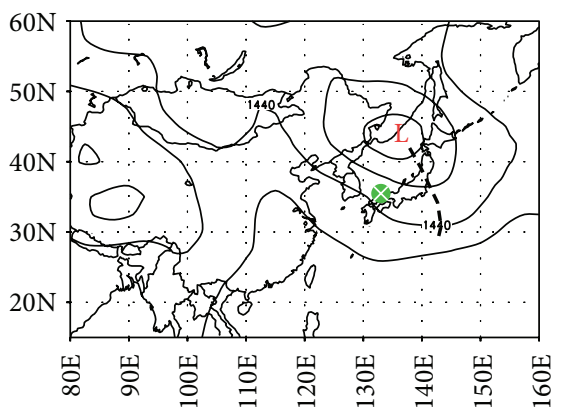

(g) 00 UTC 24 April 2006

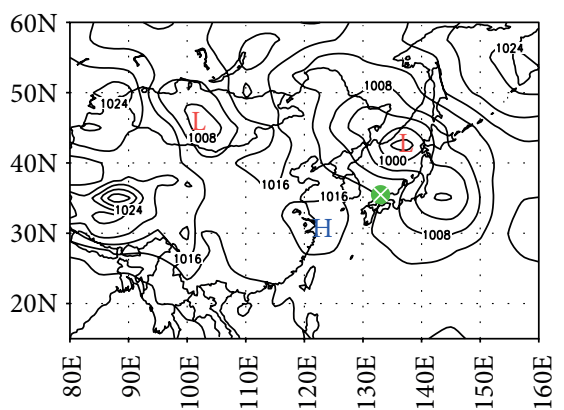

(j) 00 UTC 24 April 2006

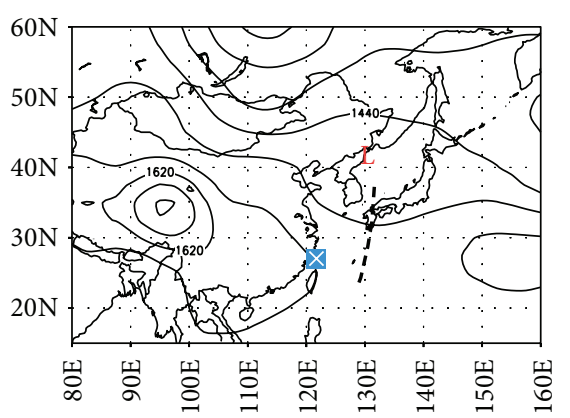

(b) 00 UTC 28 January 2007

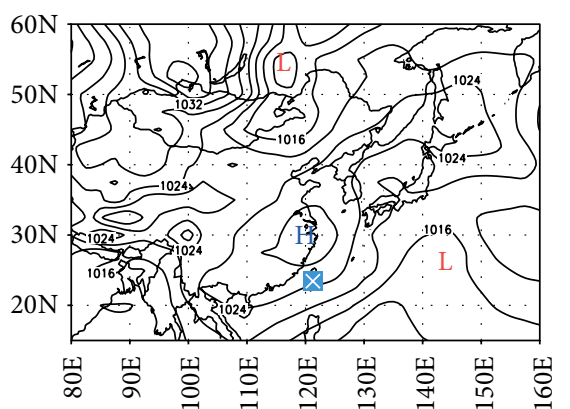

(e) 12 UTC 28 January 2007

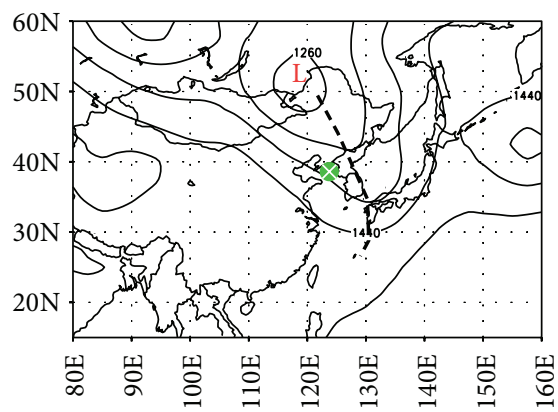

(h) 00 UTC 25 May 2007

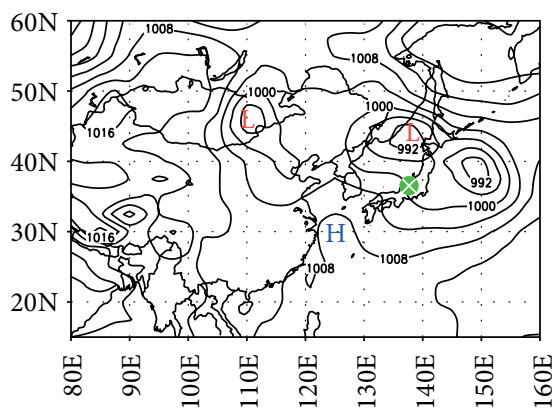

(k) 06 UTC 26 May 2007

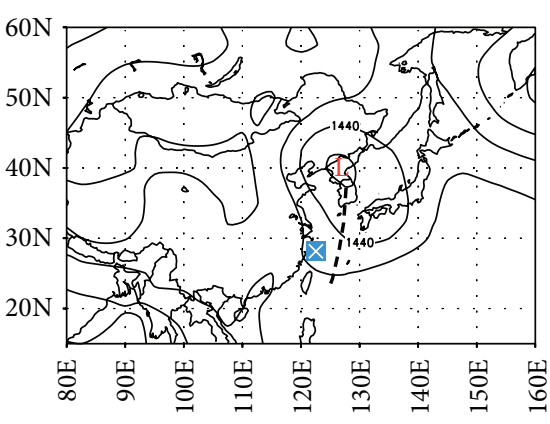

(c) 00 UTC 25 April 2009

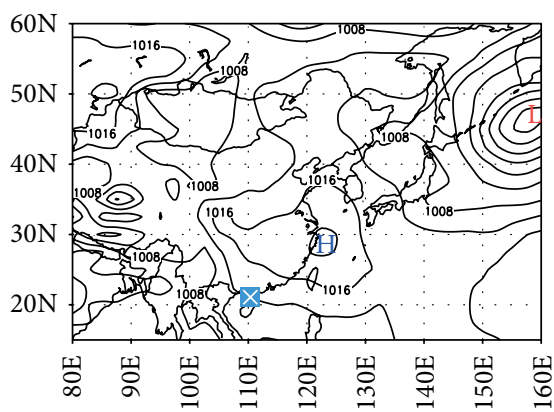

(f) 12 UTC 27 April 2009

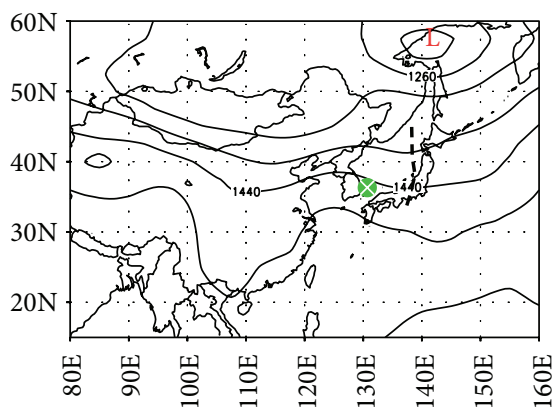

(i) 18 UTC 16 March 2009

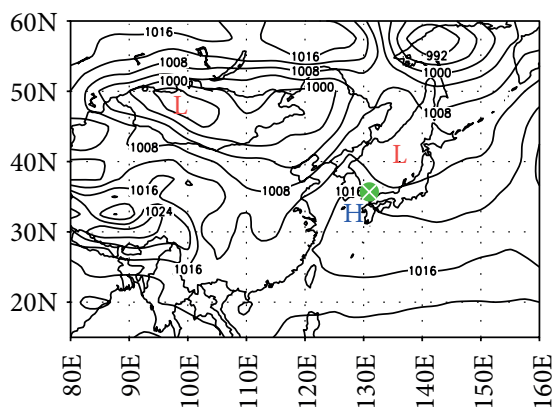

(l) 18 UTC 16 March 2009

FIGURE 9: Location of dust parcel relative to $850 \mathrm{hPa}$ and surface synoptic maps over coastal East Asia for other southeastward [(a)-(c) and (d)-(f)] and eastward [(g)-(i) and (j)-(l), respectively] dust events, except the two first events in Figures 6-8.

Figure 10 shows that during the dust transport in the free troposphere, the extent of the trough is different between eastward and southeastward transport. The trough associated with the southeastward transport event deepens and extends far southward beyond $30^{\circ} \mathrm{N}$ when moving over the eastern coast (Figure 10(a)). The prevailing northwesterlies to northerlies behind this trough carry the dust parcel almost directly southward to the low latitudes, resulting in deep southeastward transport. The rapid descent in the southeastward transport than in the eastward transport can also be attributed to the dust transport behind a deep trough where descending motion is stronger than in a shallow trough. 

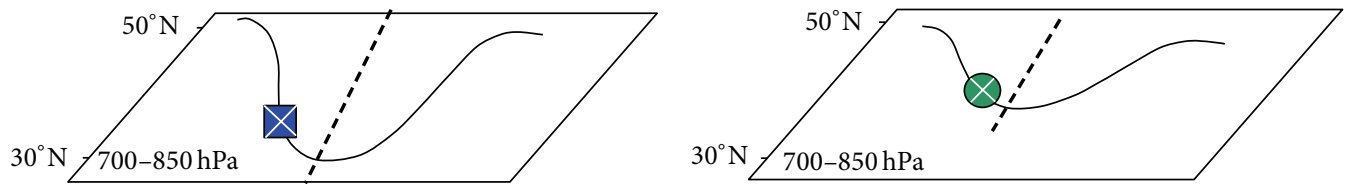

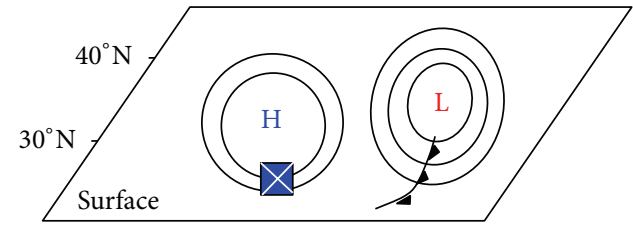

(a) Southeastward

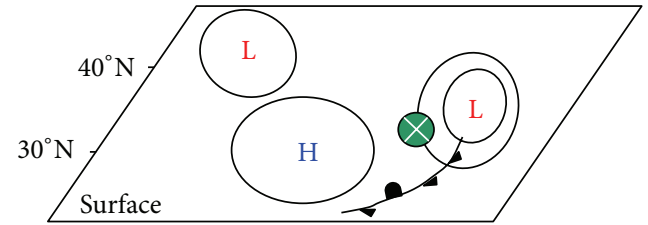

(b) Eastward

FIGURE 10: Schematic diagram showing the locations of the traced dust parcels (circle or square with $\mathrm{x}$ ) relative to synoptic maps in the lower troposphere and at surface for (a) southeastward- and (b) eastward-moving events. Lower-level trough (heavy dash line) and surface front (solid line with triangle) are plotted. High- $(\mathrm{H})$ and low- $(\mathrm{L})$ pressure systems are marked.

Similar phenomena are not seen in the eastward transport dust event because the trough is shallower and remains north of $30^{\circ} \mathrm{N}$ when moving over the eastern coast (Figure 10(b)). Dust clouds follow the westerlies to northwesterlies behind the shallower trough moving mainly eastward rather than southward.

Furthermore, when both dust events move off the coast to downwind areas, they also descend behind the associated surface front locating around the southern or eastern rim of the anticyclone. The associated anticyclonic circulations of the southeastward dust events are strong and cover a wide area of East and Southeast China, with a maximum pressure of more than $1020 \mathrm{hPa}$ reaching south beyond $30^{\circ} \mathrm{N}$. The surface anticyclone in the southeastward event moves southeastward immediately behind the dust parcel. Thus, under the rapid movement of the system and the strong northerlies to the east of the surface anticyclone, the southeastward transport dust event continues to move southward following the circulation. Since intense surface anticyclones often associated with strong surface winds and severe dust events, southeastward dust events often related to strong dust events.

For the eastward event, the anticyclonic circulation is weak, with maximum pressure less than $1020 \mathrm{hPa}$ locating north of $30^{\circ} \mathrm{N}$ when moving over the eastern coast. The weak and slow movement of the anticyclone and the leading frontal system in the eastward transport event result in the persistence of the anticyclonic circulation, and thus the dust clouds over the midlatitudes.

The arrival of eastward dust events can affect the air quality over the coastal East Asia, while southeastward dust transport over the subtropical areas can have significant impacts not only on the air quality of the areas but also on the marine biogeochemistry by providing crustal nutrients to these nutrient-limited areas [12-14, 17, 18].

\section{Conflict of Interests}

The authors declare that there is no conflict of interests regarding the publication of this article.

\section{Acknowledgments}

The authors gratefully acknowledge National Oceanic and Atmospheric Administration (NOAA) Air Resources Laboratory (ARL) for providing the HYSPLIT model (http:// www.arl.noaa.gov/ready.html) for use in this paper. The authors would also like to thank Dr. Nobuo Sugimoto of the National Institute for Environmental Studies in Japan for providing the Matsue lidar data on the lidar network (http://www-lidar.nies.go.jp/) for use in the paper. The authors also appreciate the Japanese Meteorological Agency for providing the information of dust event (http:// www.data.kishou.go.jp/obs-env/kosahp/kosa_table_2006 .html). The authors also thank two reviewers' suggestions. This study was supported by NSC 102-2611-M-0190-017-

\section{References}

[1] M. Uematsu, R. A. Duce, J. M. Prospero, L. Chen, J. T. Merrill, and R. L. McDonald, "Transport of mineral aerosol from Asia over the North Pacific ocean," Journal of Geophysical Research, vol. 88, no. 9, pp. 5342-5352, 1983.

[2] I. G. McKendry, J. P. Hacker, R. Stull, S. Sakiyama, D. Mignacca, and K. Reid, "Long-range transport of Asian dust to the Lower Fraser Valley, British Columbia, Canada," Journal of Geophysical Research D, vol. 106, no. 16, pp. 18361-18370, 2001.

[3] J. Sun, M. Zhang, and T. Liu, "Spatial and temporal characteristics of dust storms in China and its surrounding regions, 1960-1999: relations to source area and climate," Journal of Geophysical Research D, vol. 106, no. 10, pp. 10325-10333, 2001.

[4] X. Y. Zhang, R. Arimoto, and Z. S. An, "Dust emission from Chinese desert sources linked to variations in atmospheric circulation," Journal of Geophysical Research D, vol. 102, no. 23, pp. 28041-28047, 1997.

[5] B. Laurent, B. Marticorena, G. Bergametti, and F. Mei, "Modeling mineral dust emissions from Chinese and Mongolian deserts," Global and Planetary Change, vol. 52, no. 1-4, pp. 121141, 2006.

[6] Y. Iwasaka, H. Minoura, and K. Nagaya, "The transport and spacial scale of Asian dust-storm clouds: a case study of the 
dust-storm event of April 1979 ( China, Japan Islands)," Tellus $B$, vol. 35, no. 3, pp. 189-196, 1983.

[7] Y. S. Chung, "On the observations of yellow sand (dust storms) in Korea," Atmospheric Environment A, vol. 26, no. 15, pp. 27432749, 1992.

[8] Y. Chun, K. O. Boo, J. Kim, S. U. Park, and M. Lee, "Synopsis, transport, and physical characteristics of Asian dust in Korea," Journal of Geophysical Research D, vol. 106, no. 16, pp. 1846118469, 2001.

[9] T. H. Liu, F. Tsai, S. C. Hsu et al., "Southeastward transport of Asian dust: source, transport and its contributions to Taiwan," Atmospheric Environment, vol. 43, no. 2, pp. 458-467, 2009.

[10] I. Mori, M. Nishikawa, T. Tanimura, and H. Quan, "Change in size distribution and chemical composition of kosa (Asian dust) aerosol during long-range transport," Atmospheric Environment, vol. 37, no. 30, pp. 4253-4263, 2003.

[11] F. Tsai, T. H. Liu, S. C. Liu, T. Y. Chen, T. L. Anderson, and S. J. Masonis, "Model simulation and analysis of coarse and fine particle distributions during ACE-Asia," Journal of Geophysical Research, vol. 109, no. 19, 2004.

[12] J. Li, Z. Han, and R. Zhang, "Model study of atmospheric particulates during dust storm period in March 2010 over East Asia," Atmospheric Environment, vol. 45, no. 24, pp. 3954-3964, 2011.

[13] S. H. Wang, S. C. Tsay, N. H. Lin et al., "First detailed observations of long-range transported dust over the northern South China Sea," Atmospheric Environment, vol. 45, no. 27, pp. 4804-4808, 2011.

[14] C. M. Liu, C. Y. Young, and Y. C. Lee, "Influence of Asian dust storms on air quality in Taiwan," Science of the Total Environment, vol. 368, no. 2-3, pp. 884-897, 2006.

[15] I. I. Lin, J. P. Chen, G. T. F. Wong, C. W. Huang, and C. C. Lien, "Aerosol input to the South China Sea: results from the MODerate resolution imaging spectro-radiometer, the quick scatterometer, and the measurements of pollution in the troposphere sensor," Deep-Sea Research Part II, vol. 54, no. 1415, pp. 1589-1601, 2007.

[16] J. Zhao, F. Zhang, Y. Xu et al., "Chemical characteristics of particulate matter during a heavy dust episode in a coastal city, Xiamen, 2010," Aerosol and Air Quality Research, vol. 11, no. 3, pp. 300-309, 2011.

[17] S. H. Wang, N. C. Hsu, S. C. Tsay et al., "Can Asian dust trigger phytoplankton blooms in the oligotrophic northern South China Sea?" Geophysical Research Letters, vol. 39, no. 5, Article ID L05811, 2012.

[18] F. Tsai, Y. S. Fang, and S. J. Huang, "Case study of Asian dust event on March 19-25, 2010 and its impact on the marginal sea of China," Journal of Marine Science and Technology, vol. 21, no. 3, pp. 353-360, 2013.

[19] M. Liu, D. L. Westphal, S. Wang et al., "A high-resolution numerical study of the Asian dust storms of April 2001," Journal of Geophysical Research D, vol. 108, no. 23, pp. 1-21, 2003.

[20] R. R. Dickerson, C. Li, Z. Li et al., "Aircraft observations of dust and pollutants over northeast China: insight into the meteorological mechanisms of transport," Journal of Geophysical Research D, vol. 112, no. 24, Article ID D24S90, 2007.

[21] J. Y. Yu, Y. M. Cuo, and J. Y. Tu, "On the space-time characteristics of East Asian dust strom," Environmental Protection, vol. 25, no. 2, pp. 178-198, 2002 (Chinese).

[22] F. Tsai, G. T. J. Chen, T. H. Liu, W. D. Lin, and J. Y. Tu, "Characterizing the transport pathways of Asian dust," Journal of Geophysical Research, vol. 113, no. 17, 2008.
[23] W. N. Chen, S. Y. Chang, C. C. K. Chou, Y. W. Chen, and J. P. Chen, "Study of relationship between water-soluble $\mathrm{Ca}^{2+}$ and lidar depolarization ratio for spring aerosol in the boundary layer," Atmospheric Environment, vol. 41, no. 7, pp. 1440-1455, 2007.

[24] A. Shimizu, N. Sugimoto, I. Matsui et al., "Continuous observations of Asian dust and other aerosols by polarization lidars in China and Japan during ACE-Asia," Journal of Geophysical Research D, vol. 109, no. 19, Article ID D19S17, 2004.

[25] D. Liu, Z. Wang, Z. Liu, D. Winker, and C. Trepte, "A height resolved global view of dust aerosols from the first year CALIPSO lidar measurements," Journal of Geophysical Research D, vol. 113, no. 16, Article ID D16214, 2008.

[26] E. Kalnay, M. Kanamitsu, R. Kistler et al., "The NCEP/NCAR 40-year reanalysis project," Bulletin of the American Meteorological Society, vol. 77, no. 3, pp. 437-471, 1996.

[27] F. T. Jeng, J. S. Chang, K. H. Chang, H. Huang, and T. Liu, Taiwan Air Quality Model User Manual, Graduate Institute of Environmental Engineering, National Taiwan University, Taipei, Taiwan, 2000 (Chinese).

[28] R. A. Anthes and T. T. Warner, "Development of hydrodynamic models suitable for air pollution and other mesometeorological studies," Monthly Weather Review, vol. 106, pp. 1045-1078, 1978.

[29] J. Dudhia, "A nonhydrostatic version of the Penn State-NCAR mesoscale model: validation tests and simulation of an Atlantic cyclone and cold front," Monthly Weather Review, vol. 121, no. 5, pp. 1493-1513, 1993.

[30] G. A. Grell, J. Dudhia, and D. R. Stauffer, "A description of the fifth generation Penn State/MCAR mesoscale model (MM5)," Technical Note NCAR/TN-398+STR, National Center for Atmospheric Research, Boulder, Colo, USA, 1994.

[31] Z. Wang, H. Ueda, and M. Huang, "A deflation module for use in modeling long-range transport of yellow sand over East Asia," Journal of Geophysical Research D, vol. 105, no. 22, pp. 2694726959, 2000.

[32] A. Bott, "A positive definite advection scheme obtained by nonlinear renormalization of the advective fluxes," Monthly Weather Review, vol. 117, no. 5, pp. 1006-1015, 1989.

[33] J. Y. Yu, Y. W. Wang, and C. W. Chang, "Asian dust storm activity and its association with atmospheric circulation from 1995 to 2006," Terrestrial, Atmospheric and Oceanic Sciences, vol. 21, no. 2, pp. 375-391, 2010.

[34] R. R. Draxler and G. D. Hess, "Description of the HYSPLIT-4 modeling system," NOAA Technical Memorandum ARL-224, Environmental Research Laboratory (ERL), 1997. 

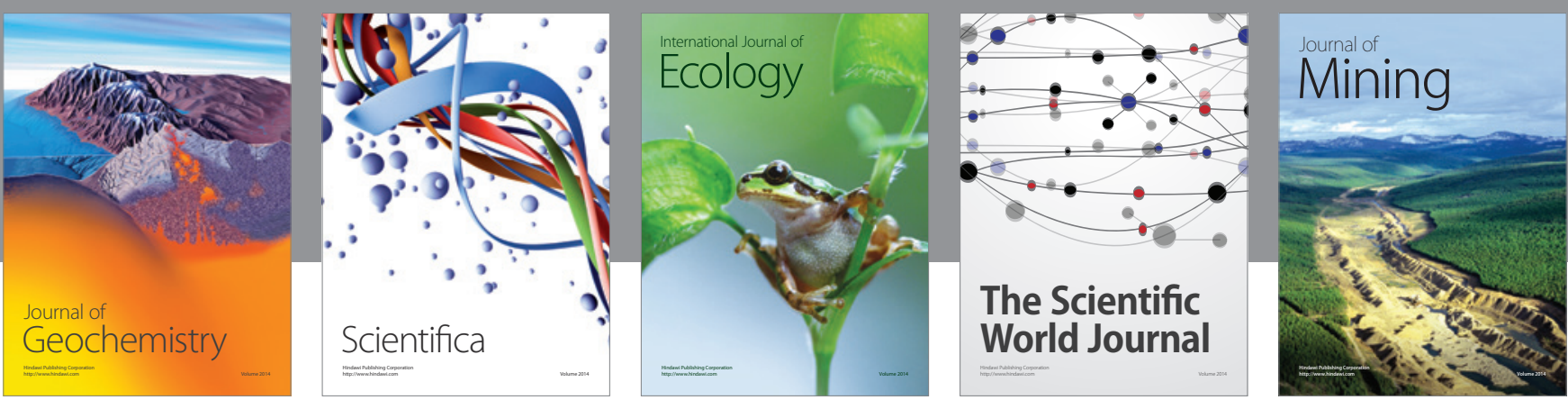

The Scientific World Journal
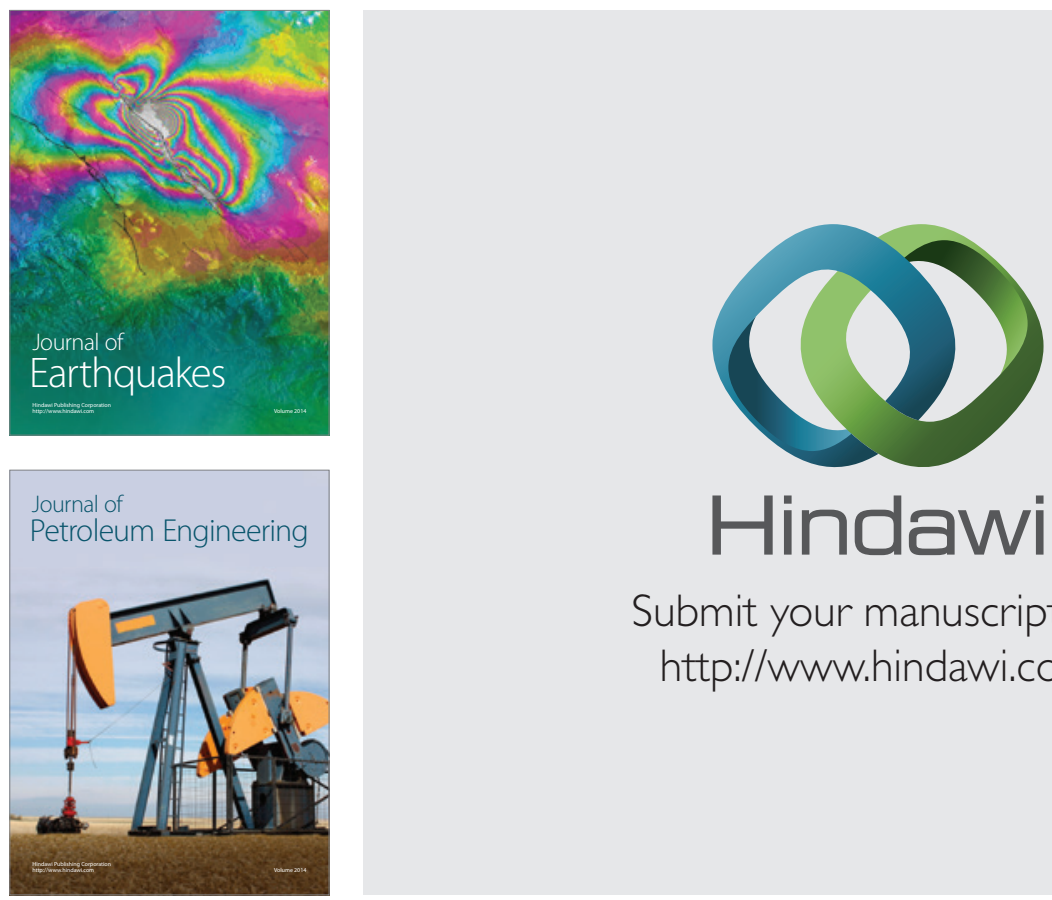

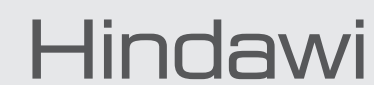

Submit your manuscripts at

http://www.hindawi.com
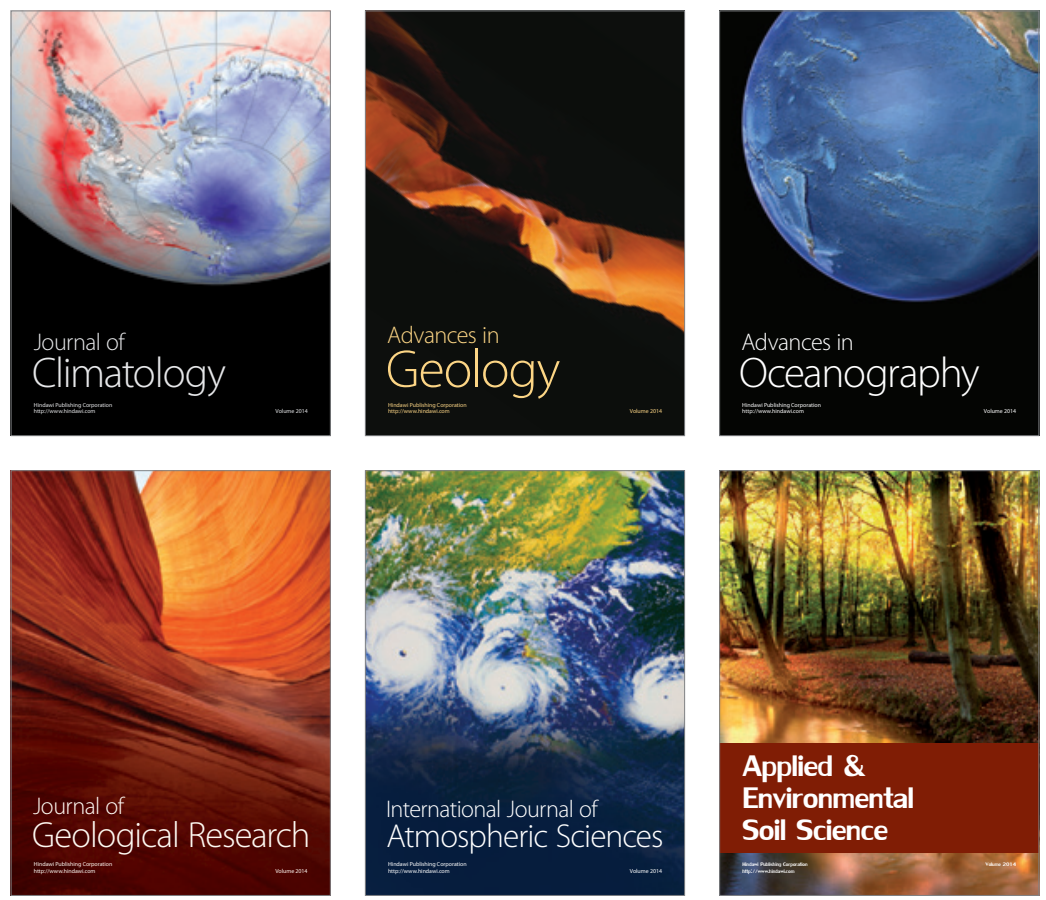
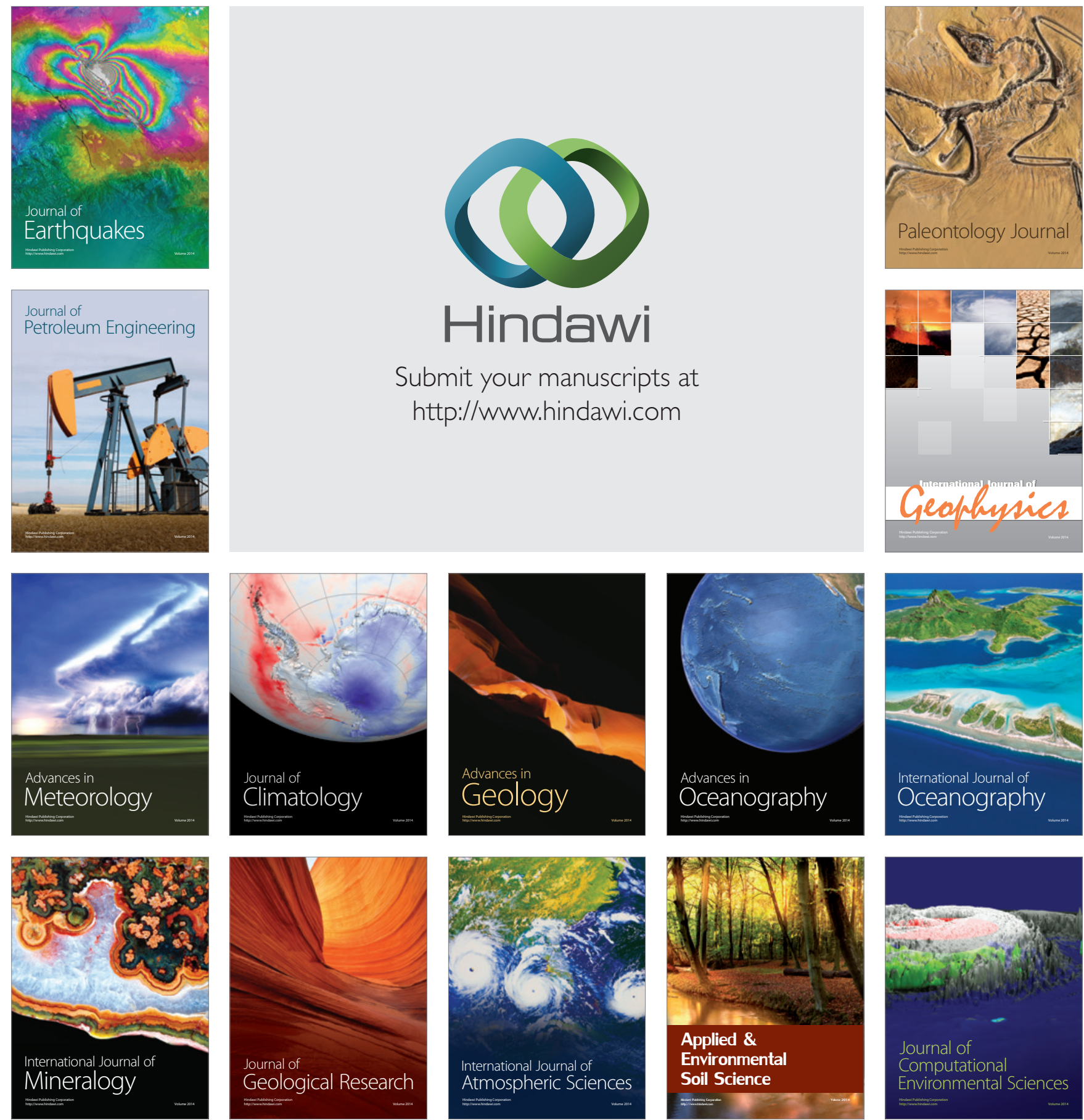